\title{
UNHAPPINESS AND AGE
}

David G. Blanchflower

Working Paper 26642

http://www.nber.org/papers/w26642

\author{
NATIONAL BUREAU OF ECONOMIC RESEARCH \\ 1050 Massachusetts Avenue \\ Cambridge, MA 02138 \\ January 2020
}

The views expressed herein are those of the author and do not necessarily reflect the views of the National Bureau of Economic Research.

NBER working papers are circulated for discussion and comment purposes. They have not been peer-reviewed or been subject to the review by the NBER Board of Directors that accompanies official NBER publications.

(C) 2020 by David G. Blanchflower. All rights reserved. Short sections of text, not to exceed two paragraphs, may be quoted without explicit permission provided that full credit, including () notice, is given to the source. 
Unhappiness and age

David G. Blanchflower

NBER Working Paper No. 26642

January 2020

JEL No. I31,P51

\begin{abstract}
$\underline{\text { ABSTRACT }}$
I examine the relationship between unhappiness and age using data from six well-being data files on nearly ten million respondents across forty European countries and the United States. I use fifteen different individual characterizations of unhappiness including despair; anxiety; loneliness; sadness; strain, depression and bad nerves; phobias and panic; being downhearted; having restless sleep; losing confidence in oneself; not being able to overcome difficulties; being under strain; feeling a failure; feeling left out; feeling tense; and thinking of yourself as a worthless person. I also analyze responses to two more general attitudinal measures regarding the situation in the respondent's country as well as on the future of the world. Responses to all these unhappiness questions show a, ceteris paribus, inverted U-shape in age, with controls and many also do so without them. The resiliency of communities left behind by globalization was diminished by the Great Recession which made it especially hard for the vulnerable undergoing a midlife crisis with few resources, to withstand the shock.
\end{abstract}

Unhappiness is hill-shaped in age. There is an unhappiness curve.

David G. Blanchflower

Bruce V. Rauner Professor of Economics

6106 Rockefeller Hall

Dartmouth College

Hanover, NH 03755-3514

and NBER

David.G.Blanchflower@Dartmouth.EDU 
There is growing evidence from around the world that prime age adults are struggling, and especially so if they have low levels of education. This is particularly apparent in the United States that has seen a rapid rise in deaths of despair, principally down to drug poisonings and suicide. Drug poisonings although at a much lower level are up in the UK and markedly so for the prime age. I document an inverted U-shape in age in various measures of unhappiness in many countries including the United States. It seems that the middle aged have had particular difficulties in adapting in the years of slow growth since the Great Recession of 2008 and 2009. The interaction between a nadir for happiness among the middle aged along with a major downturn has had major social, political and health consequences that have reverberated around the world.

Many people are hurting. All of this is happening with unemployment rates at historic lows in many countries with rates below four percent, including the Czech Republic (2.2\%); Germany (3.1\%); Hungary (3.5\%); Israel (3.4\%), Japan (2.4\%); Malta (3.4\%); Iceland (3.5\%); Mexico (3.6\%); the Netherlands (3.5\%); Norway (3.9\%); Poland (3.2\%); South Korea (3.5\%); the US (3.5\%) and the UK (3.8\%). ${ }^{1}$ This shouldn't be happening if economies were anywhere close to full employment (Blanchflower, 2019).

As William Beveridge noted in 1944, "full employment means that unemployment is reduced to short intervals of standing by, with the certainty that very soon one will be wanted in one's old job again or will be wanted in a new job that is within one's powers. ... It means that the jobs are at fair wages, of such a kind, and so located that the unemployed men can reasonably be expected to take them: it means, by consequence, that the normal lag between losing one job and finding another will be short” ([1944] 1960, 18). We are a long way from that.

I examine data from forty-one countries using multiple datasets to show the existence of an inverse U-shape, or hump shape, in age in unhappiness. There is no standard way to measure unhappiness, so I experiment with a series of alternatives. Many exhibit a hill shape in age without the inclusion of controls, and all do so with controls for gender, education, marital and labor force status. There is an unhappiness curve.

I find that this hill shape in age in unhappiness, reveals itself in fifteen different characterizations of unhappiness taken from respondents in surveys conducted in forty European countries and the United States, with table numbers where they appear below, in parentheses. Being depressed or unhappy occurs four times, with loneliness and anxiety appearing twice; the results where there are more than one the resulting estimates look remarkably similar.

1) Despair (3).

2) Anxious $(6,7)$,

3) Lonely $(8,9)$.

4) Sad (8).

5) Depressed and bad nerves $(4,5,8,9)$

\footnotetext{
${ }^{1}$ OECD Harmonised Unemployment rates; news release December 2019. https://www.oecd.org/sdd/labourstats/harmonised-unemployment-rates-oecd-12-2019.pdf and Eurostat news release 182/2019, November 2019. https://ec.europa.eu/eurostat/documents/2995521/10075437/3-29112019-BP-EN.PDF/749d647b-6961-5d3d-a8c68eaca44a539d
} 
7) Phobias and panics (4).

6) Being downhearted (9).

8) Poor sleep $(5,8)$

9) Losing confidence in yourself (5)

10) Not being able to overcome difficulties (5).

11) Being under strain (5).

12) Feeling a failure (7).

13) Feeling left out (9).

14) Feeling tense (9).

15) Thinking of yourself as a worthless person (5).

I also explore the responses to two more general measures about the situation in the respondent's country and find a hill-shape in age there also. Respondents are asked if they agree or disagree with the following statements.

16) It is hard to be hopeful about the future of the world? (7).

17) Life in the country, is getting worse? (7).

This paper is complementary to Blanchflower (2020) that looked at happiness rather than unhappiness data and showed a U-shaped relationship in age, in 132 countries, controlling for age, education, marital and labor force status and in many instances without controls. This included ninety-five developing countries and thirty-seven advanced countries. It applied to every EU28 country; every OECD country and to all five continents. The happiness curve was found using a variety of measures of well-being but was especially used happiness and life satisfaction. But a group of other measures were used including views on politics and the economy as well as with an individual's life experience including their family live, their living standards, the local area where they lived and do on. All showed a midlife dip centering around age 50. It was really hard not to find the U-shape. In this paper I show the mirror image of the U-shape happiness curve (Rauch, 2019). There is also an inverted U-shape unhappiness curve.

Subsequent to the publication of Blanchflower and Oswald (2008) Glenn (2009) argued that it was inappropriate to include controls and what mattered was the raw data; Blanchflower and Oswald (2009) disagreed. His critique related to the U-shape in happiness but the argument could plausibly be applied to the hill shape in unhappiness. Glenn claimed that: "the appearance of this U-shaped curve of well-being is the result of the use of inappropriate and questionable control variables" and especially marital status. It is worth rehearsing the arguments we used there again. In many countries around the world, and especially in Europe, as I illustrate in detail below, the U-shape can be found without any control variables, and a major problem with Glenn's analysis was that he focused too heavily on the United States.

Second, we disagreed with Glenn's methodological position, which seems to be that social scientists should not hold constant other factors when they study the relationship between wellbeing and age. Ultimately in social science, the control variables that are included in multiple regression equations we noted, have to be chosen with an eye on the intellectual or policy question being answered. The summary of our argument went as follows. If the aim is to describe the data, it is reasonable to leave out most or all control variables. 'Smokers die at rate Z' is an acceptable 
statement to make. But that is not the same as 'smoking changes your risk by Z', which requires other confounding variables to be controlled for such as diet, education, income and exercise. We argued "it would likely be an error to use an equation without controls to tell the public what impact ageing has on happiness without separating out the effects of other variables such as, say, education, marriage or unemployment. If the aim is to understand relationships", we argued, "it will rarely be desirable to stop at bivariate patterns." That seems right and I don't stop at bivariate patterns in this paper as in Blanchflower (2020), but present results with and without controls which even then mostly give inverted U-shapes, especially in the UK and the USA.

An obvious question is whether unhappiness is simply the inverse of happiness. This is what I examine here. Most of the effects found in happiness equations as I will show, do go through, so the unemployed enter significantly negatively in happiness equations and positively in unhappiness equations, for example. Similarly, with education and marital status. Country rankings also go through. Scandinavian countries like Denmark and Sweden are the happiest and the least unhappy. East European countries like Bulgaria and Romania rank very low in happiness equations and very high in unhappiness equations. Some do not. It turns out in some instances, for example, females enter positively in all but one of the unhappiness equations reported here. They also tend to enter negatively in happiness equations, see, for example Blanchflower and Oswald (2004a, 2004b, 2011) and Blanchflower (2009).

In Blanchflower and Oswald (2008) we examined U-shapes happiness and life satisfaction but also explored unhappiness and found inverted U-shapes using data on depression and bad nerves for the UK from the Labour Force Surveys of 2004Q2-2007Q2. I update those results below. We also found an inverted U-shape in mental distress across fifteen EU from Eurobarometer \#56.1. This data file contained information both on life satisfaction and six elements of the well-known General Health Questionnaire (GHQ6) mental distress score. I return to this file below also and examine the six individual components of the GHQ 6 score.

Blanchflower and Oswald (2016) examined the use of antidepressants in randomized samples from 27 European countries and show that the probability of taking antidepressants follows an inverted U-shaped curve that peaked in people's late 40s.

There is a literature with at least a dozen unhappiness variables for which there are hill shapes in age that have been subsequently estimated, starting with stress, anger and worry. Graham and Pozuelo (2017) analyzed stress in 46 individual countries, including controls for gender, education, marital and employment status and household income and found an inverted U-shaped relationship between age and stress was measured using data from the Gallup World Poll from 2005-2014 a reverse U held for stress in 34. ${ }^{2}$ Fortin et al (2015) using the same Gallup World Poll data also find evidence of an inverse U-shape in age for stress and also find the same for worry and anger in the raw data, without controls.

${ }^{2}$ Graham and Pozuelo (2017) found inverted U-shapes in stress in 34 countries - Albania; Argentina; Australia; Belgium; Bosnia; Brazil; Bulgaria; Canada; Chile; China; Colombia; Croatia; Cyprus; Czech Republic; Estonia; Greece; Hungary; India; Ireland; Latvia; Lithuania; Macedonia; Mexico; Montenegro; Peru; Portugal; Romania; Serbia; Slovakia; South Africa; Spain; UK; USA and Venezuela. The 12 countries where the stress curve did not hold are Austria, Denmark, Finland, France, Germany, Italy, Kosovo, Netherlands, Poland, Russia, Slovenia, and Sweden. 
Krueger (2017) found evidence that prime-age men and women age 25-54 were significantly more tired, sad or stressed than was the case for younger or older groups. The differences were especially marked for those not in the labor force. Kruger argued that one factor that likely contributes to the low level of emotional wellbeing of prime age, NLF men is the relatively high amount of time they spend alone. Prime age, NLF men, he found, spent nearly 30 percent of their time alone, compared with 18 percent for prime age, employed men and 17 percent for prime age, employed women.

Giuntella et al (2019) find inverted U-shapes in a further six aspects of unhappiness and two relating to feelings about suicide across a variety of countries. They also examined difficulties sleeping, being dependent on alcohol, feeling life is not worth living; finding it hard to concentrate and forgetting things, feeling overwhelmed at their workplace, and suffering from disabling headaches. The U-shape sometimes emerges without controls but most frequently with controls for education, children, marital and labor force status. There are broad similarities in their findings to the results reported here although there is only direct overlap with sleep, although the questions are slightly different.

This paper adds to the growing list of unhappiness variables that contain hill-shapes in age. I examine the relationship between unhappiness and age using data from six well-being data files across 41 countries. $^{3}$ The data sets are the Behavioral Risk Factor Surveillance System (BRFSS) survey from 1993-2018; the Annual Population Survey (APS) for the UK for 2015-2018; the Labour Force Survey (LFS) in the UK from 2014-2018; the European Social Surveys (ESS) of 2003-2016; the European Quality of Life Surveys (EQLS) of 2003-2016 and the Eurobarometer Survey \#56.1 for 2001.

It turns out that the relationship between unhappiness and age is essentially the same no matter how the question is asked, or the response scored.

\section{Background on Mental Health in Midlife}

It makes sense to first look at the survey data that exists on a number of dimensions of unhappiness, including depression, pain, mortality and suicide.

\section{a) Depression}

As background it is appropriate to take a brief look at the evidence on depression by age across countries. It seems to be consistent that rates are especially high in midlife. I also note that deaths of despair, especially among prime-age non-Hispanic whites in the US have risen in the last few years. There is evidence that this rise is especially marked among the least educated (Blanchflower, 2019). In contrast mortality rates in other advanced countries have continued to fall.

\footnotetext{
3 The forty-one countries are Albania; Austria; Belgium; Bulgaria; Croatia; Cyprus; Czech Republic; Denmark; Estonia; Finland; France; Germany; Greece; Hungary; Iceland; Ireland; Israel; Italy; Kosovo; Latvia; Lithuania; Luxembourg; Macedonia; Malta; Montenegro; Netherlands; Norway; Poland; Portugal; Romania; Russia; Serbia; Slovakia; Slovenia; Spain; Sweden; Switzerland; Turkey; Ukraine; United Kingdom and the United States.
} 
It turns out that depression rates in many advanced countries are higher in mid-life than at other ages. Data from the National Health and Nutrition Examination Survey (NHNES) for the United States 2009-2012, showed that 7.6\% of American adults aged 20 and over had depression (moderate or severe depressive symptoms) in a given 2-week period (Pratt and Brody, 2014). Depression rates were $7.4 \%$ for those age $18-39$; $9.8 \%$ for ages $40-59$ and $5.4 \%$ for those aged sixty and over.

The proportion depressed in the EU28, is broadly similar at 7.1\% in 2014, although the definition used there is 'chronic depression' and relates to the previous year. The second wave of the European health interview survey (EHIS) was conducted between 2013 and 2015 and covers persons aged 15 years and over. With $12.1 \%$, Ireland topped the ranking for the share of its population reporting chronic depression, while double-digit shares were also recorded in Germany and Finland; an even higher share was recorded in Iceland (14.8 \%), while Turkey also recorded a double-digit share $(11.0 \%)$. Table 1 plots rates by age group for fifteen European countries and for the EU28. With the exception of Finland which has a maximum in the age group 25-34 the four have peaks in the 45-54 age range (Luxembourg; Netherlands, Sweden and Turkey) while ten were in the 55-64 grouping. ${ }^{4}$

\section{b) Pain}

Case and Deaton (2015) examined data from the U.S. National Health Interview Survey and looked at changes between the mean for 2011-13 and 1997-99 for those ages 45-54 with regard to neck pain, facial pain, chronic joint pain, and sciatica, all of which showed significant increases. One in three white non-Hispanics aged 45-54 reported chronic joint pain in the 2011-13 period. This rise in pain is correlated with the rise in pain medication prescriptions. They found that the prevalence of pain was highest for those ages 35-54 with less than a high school education. The Institute of Medicine (IOM) reported (2011) a marked rise in pain between 2000 and 2009, especially for those ages 45-64 and for white non-Hispanics.

Blanchflower and Oswald (2019) found that Americans were disproportionately likely to report being in pain. Krueger (2017) found that nearly half of prime age men in the United States who are not in the labor force take pain medication on any given day; and in nearly two-thirds of these cases, they take prescription pain medication.

Carpenter, McClellan, and Rees (2017) have found robust evidence that economic downturns lead to increases in the intensity of prescription pain reliever use as well as increases in clinically relevant substance-use disorders involving opioids. These effects are concentrated among working-age white men with low educational attainment. They also find that recent use of ecstasy and heroin is significantly countercyclical, while use of LSD, crack, and cocaine is significantly procyclical. They find clear evidence that substance-use disorders involving alcohol, marijuana, analgesics, and hallucinogens are strongly countercyclical. The findings for analgesics are robust to estimation method and are consistently larger, compared with other groups, for prime-age white men with low levels of education who were hardest hit by the Great Recession. The authors argue

\footnotetext{
${ }^{4}$ Source: Mental health and related issues statistics, Eurostat https://ec.europa.eu/eurostat/statisticsexplained/index.php?title=Mental_health_and_related_issues_statistics\&oldid=390121\#Extent_of_depressive_disor $\underline{\text { ders }}$
} 
that as state budgets contract during economic downturns, drug- treatment funding, is particularly vulnerable.

Despite the widespread use of prescription opioids to treat pain, it seems they are largely ineffective. First, Moore and Hersh $(2013,898)$ in the Journal of the American Dental Association addressed the treatment of dental pain following wisdom tooth extraction and concluded that 325 milligrams of acetaminophen taken with 200 milligrams of ibuprofen provides better pain relief than oral opioids. Second, a review article in the Spine Journal (Lewis et al. 2013) looked at multiple treatment options for sciatica (back pain with a pinched nerve with symptoms radiating down one leg) and found that non-opioid medications provided some positive global effect on the treatment of the disorder, while the opioids did not.

c) Mortality

Case and Deaton (2015) also documented rising mortality rates for white non-Hispanic men and women ages 45-54 in the United States between 1999 and 2013. Death rates for this group rose both absolutely and relative to other racial and ethnic groups. The rising rate of "deaths of despair," as they call them, is due to drug and alcohol poisoning and suicide, which disproportionately impact the middle-aged but especially white non-Hispanic middle-aged.

In a follow-up paper Case and Deaton (2017) noted that increases in all-cause mortality in the USA continued unabated to 2015, with additional increases in drug overdoses, suicides, and alcoholicrelated liver mortality, particularly among those with a high school degree or less. The decline in mortality from heart disease, they reported, has slowed and, most recently, stopped, and this combined with the three other causes is responsible for the increase in all-cause mortality. Their main finding is that educational differences in mortality among whites are increasing, but mortality is rising for those without, and falling for those with, a college degree. This is true for white nonHispanic men and women in all age groups from 25-29 through 60-64. Mortality rates among blacks and Hispanics continue to fall; in 1999, the mortality rate of white non-Hispanics aged 5054 with only a high school degree was 30 percent lower than the mortality rate of blacks in the same age group; by 2015, it was 30 percent higher.

My Dartmouth colleague Paul Novosad and Charlie Rafkin (2019) found that middle-age mortality increases among non-Hispanic whites have been driven almost entirely by changes in the bottom $10 \%$ of the education distribution. They show that death rates for the least educated have dramatically diverged from death rates of other groups, in virtually all middle-age race and gender groups. Non-Hispanic whites in the least educated 10\% have done particularly poorly.

Woolf and Schoomaker (2019) note that between 1959 and 2016, US life expectancy increased from 69.9 years to 78.9 years but declined for 3 consecutive years after 2014. The recent decrease in US life expectancy they point out, culminated a period of increasing cause-specific mortality among adults aged 25 to 64 years that began in the 1990s, ultimately producing an increase in allcause mortality that began in 2010. During 2010-2017, midlife all-cause mortality rates increased from 328.5 deaths/100,000 to 348.2 deaths/100,000. By 2014, midlife mortality was increasing across all racial groups, caused by drug overdoses, alcohol abuse, suicides, and a diverse list of organ system diseases. 
The ONS (2018) noted that the US was the only country to experience an increase in standardized deaths for those age 40-64 between 2011 and 2016, for both men and women. The UK, Sweden, Spain, Portugal, Norway, Netherlands Japan, Italy Germany France, Finland Denmark Belgium and Australia. Japan experienced a 17\% improvement for males and $16 \%$ for females while Finland had improvements of $15 \%$ and $13 \%$ respectively.

ONS (2018) further noted that even though the US experienced an 11\% improvement over the previous period, 2001-2011 this was the least improvement of all the countries studied. Over that period UK males aged 40 to 64 years experienced a 21\% improvement in standardized deaths between 2001 and 2011; this was the same as Sweden, Denmark and Spain. Only Norway (22\%), Italy (25\%) and the Netherlands (27\%) experienced greater improvements over this period. The US

d) Suicide

Hedegaard , Curtin and Warner (2018) reported that suicide rates for both males and females per 100,000 by age have risen in the USA as below between 2000 and 2016. Rates in the two midlife age categories rose for both and strongly so for men over these years.

\begin{tabular}{lclcl} 
& \multicolumn{2}{c}{ Males } & \multicolumn{2}{c}{ Females } \\
& 2000 & 2016 & 2000 & 2016 \\
Age 15-24 & 17.1 & 20.5 & 3.0 & 5.4 \\
Age 25-44 & 21.3 & 28.2 & 5.4 & 7.6 \\
Age 45-64 & 21.3 & 29.1 & 6.2 & 9.9 \\
Age 65-74 & 22.7 & 25.9 & 4.0 & 6.2 \\
Age 75+ & 42.4 & 39.2 & 4.0 & 4.2
\end{tabular}

Table 2 shows that overall suicide rates in the US grew from 10.8\% to $13.9 \%$ over this period. Rates fell in Australia, Belgium, Denmark, Finland, France, Germany, Ireland, Japan, Norway, Spain, Sweden, and Switzerland and were flat in the UK and Canada.

\section{e) Drug poisonings}

In the United States drug overdoses resulted in 702,568 deaths during 1999-2017, with 399,230 (56.8\%) involving opioids. ${ }^{5}$ Drug overdoses resulted in 70,237 deaths in 2017 of which 47,600 deaths involved opioids. Hedegaard, Miniño and Warner (2018) report that the rates of drug overdose deaths increased over this period for all age groups.

$\begin{array}{lcc} & 1999 & 2017 \\ 15-24 & 3.2 & 12.6 \\ 25-34 & 8.1 & 38.4 \\ 35-44 & 14.0 & 39.0 \\ 45-54 & 11.1 & 37.7 \\ 55-64 & 4.2 & 28.0 \\ \geq 65 & 2.7 & 6.9\end{array}$

${ }^{5}$ See Scholl et al (2019). 
The highest incidence of drug poisonings in 2017 was for those age 35-44 with ages 25-34 and 4554 close behind. Quinones (2015) and Arnade (2019) provides helpful insights into the emerging opioid crisis and the difficulties the left-behinds face coping. In the US those with criminal records struggled to find jobs and many could not pass drug tests. as employers wanted to avoid hiring them.

In contrast in the European Union Drug report showed that there were around 8200 overdose deaths involving illicit drugs in the European Union in 2017. The UK (34\%) and Germany (13\%) together account for around a half of the deaths. The European Drug Report of 2017 showed a rise in the number of drug-induced deaths in 2014 and 2015. ${ }^{6}$ It showed the highest number of deaths in the 35-39 (1,191 in 2014 and 1,312 in 2015) age range.

The ONS reports that there were 4,359 deaths due to drug poisonings in England and Wales in 2018, the highest since the series began in $1993 .{ }^{7}$ Below I report age-specific mortality rates per million people. Rates of male deaths have doubled over the period. The highest rates in 2018 are for those ages 40 to 49 that have seen a $750 \%$ rise.

$\begin{array}{lrr}\text { Registered year } & 1993 & 2018 \\ \text { Under } 20 & 3.9 & 3.6 \\ 20 \text { to } 29 & 34.7 & 49.9 \\ 30 \text { to } 39 & 28.5 & 98.9 \\ 40 \text { to } 49 & 16.5 & 125.7 \\ 50 \text { to } 69 & 9.5 & 46.8 \\ 70 \text { and over } & 15.3 & 11.2 \\ \text { Men } & 51.5 & 105.4 \\ \text { Women } & 34.2 & 47.5 \\ \text { All } & 42.9 & 76.3\end{array}$

The published data does suggest a midlife crisis with the United States looking worse than any other country. So, I start there.

\section{Empirical Analysis}

a) Despair and Extreme Mental Health in the USA

Table 3 makes use of data from the 1993-2018 BRFSS data files, for the United States with nearly 8 million observations. I make use of the data first developed by Blanchflower and Oswald (2020) from a question which asks as follows.

Q1. "Now thinking about your mental health, which includes stress, depression, and problems with emotions, for how many days during the past 30 days was your mental health not good?

\footnotetext{
${ }^{6}$ The European Drug Report 2017, July 2019 http://www.emcdda.europa.eu/publications/edr/trendsdevelopments/2017/html/harms-responses/overdose-deaths en

${ }^{7}$ Deaths related to drug poisoning in England and Wales; 2018 registrations', ONS 15 ${ }^{\text {th }}$ August 2019 https://www.ons.gov.uk/peoplepopulationandcommunity/birthsdeathsandmarriages/deaths/bulletins/deathsrelatedtod rugpoisoninginenglandandwales/2018registrations
} 
The weighted mean of this variable has risen from 2.9 in 1993 to 3.4 in 2008 and 3.9 in 2018. Chart 1a plots the mean mental health days by single year of age without controls and then with controls for gender, marital and labor force status and education. There is no obvious U-shape pattern in age. But there is when I examine those most in despair in the data. I refer to these individuals as being in despair; an alternative of course is to refer to them as being in extreme mental distress.

In response to the question above answers are distributed from zero to thirty. Averaged across these years with sample weights imposed two-thirds of the sample say zero, but $4.9 \%$ say thirty out of thirty. I classify such individuals as being in 'despair'. Notably the percentage saying 30/30 were not good has risen sharply since 1993, when it was 3.6\% to 6\% in 2018. Blanchflower and Oswald show this rise is especially apparent for prime-age less educated whites, who Case and Deaton $(2015,2017)$ have shown have disproportionately experienced deaths of despair. I create a variable called 'despair' which is set to one if the respondent says 30 of the last 30 days were not good, zero otherwise. It makes little if any difference if instead I classify people as being in despair as being, say from 20-30 days. For example, in 2017 using sample weights $5.9 \%$ of the sample were in the top 30-day category with only an additional $1.1 \%$ between 20 and 29 days.

Table 3 reports the results of estimating a series of OLS equations with despair as the dependent variable and seven age variables. In column 1 without any controls that rise steadily through the 50-59 band and then fall back in the first column which only has year dummies. In the second column when controls for gender, education, marital status and employment are added the high point is in the forties as it is in the third column when cohort dummies are added. The last two columns include personal and cohort controls and split the sample into High school diploma and less and some college. There is an inverted U-shape in both and especially so for the least educated, but the steady rise in the cohort effects is apparent for the least educated.

In these unhappiness equations, men are less unhappy. The employed are less unhappy than the unemployed and those unable to work are most happy. Married people are less unhappy than the never married and much higher than separated and college graduates are less unhappy than high school dropouts. The same patterns repeat in the remaining tables.

Chart $1 \mathrm{~b}$ also uses despair, derived from the BRFSS not good mental health days question, but this time limiting the sample to those with less than a high school diploma, for non-Hispanic whites $(n=431,938)$, then to non-whites $(n=303,045)$, both with less than a high school education and without controls and the coefficients of the single year of age dummies, with the equation including year dummies for the period 1993-2018 are plotted. Both show a U-shape which is higher for whites, peaking at around $4 \%$ versus $11 \%$ for no-whites. Chart $1 \mathrm{c}$ repeats the same plot but now for the most recent data, and once again the white peak $(n=34,887)$ is above that for non-whites but peaks of the whites has risen to around $22 \%$ whereas that for non-whites $(n=33,443)$ is little changed, at $12 \%$. The chart confirms the worsening experience of less educated whites in recent years.

\section{b) Depression and bad nerves in the UK}

An inverted U-shape in a depression measure was shown to exist in Blanchflower and Oswald (2008b) in relation in a sample of over a million in relation to the incidence of depression in the 
UK. ${ }^{8}$ The data file used was the Labour Force Survey from 2004Q2-2007Q1 and depression was obtained using responses to the main health problem respondents reported - which was depression and bad nerves. The raw data were plotted (their Figure 1) which showed an obvious inverted U-shape. Probit regressions were run (their Table 7) which showed the inverted U-shape using a quadratic in age without controls and then with controls for region of residence, education, marital and labour force status.

I updated this analysis with the most recent data available for the period 2014-2018 with more than 1.3 million observations. There has been a steady rise in depression in the couple of years since the Brexit vote, according to these data, from 2.4\% in 2014 to 2.7\% in 2016; 2.9\% in 2016; 3.3\% in 2017 and $3.6 \%$ in 2018 with sample weights imposed. I first plot the data without controls and then with controls for gender, marital and labor force status and education. Chart 2a plots single year of age dummies with and without controls and both trace out obvious U-shapes. Columns 1 and 2 of Table 4 models depression and confirms the inverted U-shape. Married people and the employed and the most highly educated and men are less likely to be depressed. The picture is essentially identical to that found for the period a decade earlier.

\section{c) Phobias and panics in the UK}

The LFS files also contain data on phobias and panics that Blanchflower and Oswald (2008) did not examine. ${ }^{9}$ This variable has a much lower incidence than depression does although that has also seen a small increase since the Brexit vote in 2016 (1.1\% in 2014 and 2015; 1.2\% in 2016; $1.3 \%$ in 2017 and 2018).

Chart 2b shows there is no inverted U-shape without controls but there is one with them. Columns 3 and 4 of Table 4 shows an inverted U-shape with controls but not without them. Of note here is the positive sign on the male coefficient. The other variables tell a similar story to depression, married, the educated and the employed have lower likelihood of reporting phobias or panic attacks.

\section{d) Sleep, strain; unhappy and depressed, can't overcome difficulties, losing confidence and feeling worthless}

Blanchflower and Oswald (2008) identified a hump-shape between the so-called GHQ (General Health Questionnaire) psychiatric measure and age using data from \#56.1 Eurobarometer. ${ }^{10}$ For the uninitiated GHQ is a measure of psychological distress that comes from amalgamating answers to the following six questions.

Have you recently:

Q2. Lost much sleep over worry?

Q3. Felt constantly under strain?

Q4. Felt you could not overcome your difficulties?

\footnotetext{
${ }^{8}$ Bell and Blanchflower (2019) showed that there has been a marked rise over the years in the incidence of depression from $0.6 \%$ in 1997 to $1.5 \%$ in the years $2004-2007$ to $3.6 \%$ in 2018.

${ }^{9}$ The exact wording is 'mental illness, phobias and panics'.

${ }^{10}$ Clark and Oswald (1994) found an inverted U-shape for the UK using a 12 item GHQ unhappiness score.
} 
Q5. Been feeling unhappy and depressed?

Q6. Been losing confidence in yourself?

Q7. Been thinking of yourself as a worthless person?

To the answers to each of these six, the integers $0,1,2$, 3 were assigned depending whether each was answered not at all, no more than usual, rather more than usual, much more than usual. The numerical answers were then summed. Overall, a GHQ mental distress score which must by definition lie between 0 and 18; the higher the score the more distress. We found that there was an inverted U-shape in age across countries with this GHQ6 variable, with or without personal controls. But we did not investigate the individual components of the score. That is what I do in Table 5, with and without controls. In all six examples there is an inverted U-shape with and without controls.

Chart 3 is of interest as it plots the single year if age dummies with controls with GHQ6 and life satisfaction variables that are both asked in Eurobarometer \#56.1. The two series look to be mirror images of each other with a minimum in happiness and a maximum in unhappiness around age 50.

\section{e) Anxiety}

Table 6 examines data on anxiety from the large micro data files from the Annual Population Survey collected by the Office of National Statistics. This is the one major survey used to calculate labor market data including the unemployment rate that includes well-being questions, which it has been doing since 2011. I examine the most recent data available for 2016-2018, for a question on anxiety with the exact wording as follows. ${ }^{11}$

Q8. Anxious (1). - On a scale where nought is 'not at all anxious' and 10 is 'completely anxious', overall, how anxious did you feel yesterday?

Both with and without controls there is evidence of an inverted U-shape in anxiety, maximizing once again in the 50-59 age band. Chart 4 shows inverted U-shapes with and without controls when the single year of age controls which are added to the constant, plus two, year dummies are included. This contrasts precisely with U-shapes in age in these same data files using life satisfaction and happiness reported in Blanchflower (2020).

Column 1 of Table 7 also examines anxiety, using data from waves 3 and 6 the European Social Survey. ${ }^{12}$ The question is somewhat different to the one asked in the UK.

Q9. Anxious (2). How often over the past week have you felt anxious? All of the time =6; most of the time =5; more than half of the time $=4$; less than half of the time=3; some of the time=2; at no time $=1$ ?

In contrast to the UK as shown in column 1 of Table 7 there is no obvious U-shape in the raw data in anxiety, which seems to rise with age. There is more evidence of an inverted U-shape in the next question examined in Table 5, for feeling a failure.

\footnotetext{
${ }^{11}$ Bell and Blanchflower (2019) also find an inverted U-shape in the UK in anxiety with these data.

${ }^{12}$ The appendix reports the regression results for the variables in Tables 5 and 6 without controls, which mostly do not show inverted U-shapes.
} 
Controls are included for gender, marital and labor force status and education and there is again evidence of a rise in anxiety to midlife and then a fall back in later life. This time the maximum is in the 40-49 age band.

\section{f) Feeling a failure (ESS)}

In column 2 of Table 7 unhappiness is now measured by reference to a question on whether the individual feels they are a failure. The inverted U-shape is present again.

Q10. At times I feel a failure? Disagree strongly=1; disagree=2; neither agree nor disagree=3; agree $=4$ and agree strongly $=5$.

\section{g) For most people life is getting worse and it is hard to be hopeful about the future of the world (ESS)}

The final two columns of Table 7 refer more broadly to an individual's views on unhappiness in society as a whole, contained in waves 3 and 6 of the ESS.

I am also interested in how much more broadly the inverted U-shape occurs given the evidence presented in Blanchflower (2020) that the U-shape was found in many variables relating to living standards, politics and economics including the state of the national economy. In sweeps 3 and 6 of the ESS respondents were asked the following

Q11. Hard to be hopeful about the future of the world -Disagree strongly=1; disagree=2; neither agree nor disagree $=3$; agree $=4$ and agree strongly $=5$.

Q12. For most people in country life is getting worse - Disagree strongly=1; disagree =2; neither agree nor disagree $=3$; agree $=4$ and agree strongly $=5$

In answer to Q11 22\% agree and 3\% agree strongly while in Q12 38\% agree and 21\% agree strongly. There is evidence of an inverted U-shape in age in both suggesting the unhappiness hill shape may have broader applicability.

\section{h) Loneliness (1), Sadness, Depression and Restless Sleep}

Table 8 now turns to other ways of distinguishing unhappiness in European countries in sweeps 3, 6 and 7 of the ESS. The four questions asked were as follows.

Q13. Lonely. Felt lonely last week? None or almost none of the time=1; some of the time=2; most of the time=3; all or almost all of the time $=4$ ?

Q14. Sad. Felt sad, how often over the past week? None or almost none of the time=1; some of the time $=2$; most of the time $=3$; all or almost all of the time $=4$ ?

Q15. Depressed. Felt depressed how often past week? None or almost none of the time=1; some of the time=2; most of the time=3; all or almost all of the time $=4$ ?

Q16. Sleep. Sleep was restless how often past week? None or almost none of the time $=1$; some of the time $=2$; most of the time=3; all or almost all of the time $=4$ ? 
Table 8 shows that with controls there are inverted U-shapes in every case.

\section{i) Loneliness (2); feeling downhearted and depressed, left out and tense}

I examined the responses in the ESS above to a question on loneliness in the last week. Table 7 uses data from the EQLS 2004-2016 for 35 European countries and shows on a number of dimensions being left-out, tired, tense or downhearted and depressed, generate a ceteris paribus inverted U-shapes with controls. In the EQLS the question on loneliness was similar but related to the previous two weeks as it did to the other three questions. The data are taken from waves 3 and 4 except left out which also is in wave 2.

Q17. Lonely. Please indicate for each of the statements which is closest to how you have been feeling over the last two weeks. I have felt lonely - at no time==1; some of the time=2; less than half time $=3$; more than half the time $=4$; most of the time $=5$; all of the time $=6$.

Q18. Down. Please indicate for each of the statements which is closest to how you have been feeling over the last two weeks. I have felt downhearted and depressed - at no time==1; some of the time=2; less than half time=3; more than half the time=4; most of the time=5; all of the time $=6$.

Q19. Left out. Please indicate for each of the statements which is closest to how you have been feeling over the last two weeks. I feel left out of society-never=1; less often/rarely=2; several times a year=3; several times a month=4; several times a week=5).

Q20. Tense. Please indicate for each of the statements which is closest to how you have been feeling over the last two weeks. I have felt particularly tense - at no time==1; some of the time $=2$; less than half time=3; more than half the time=4; most of the time=5; all of the time=6.

Table 9 shows that with controls there is, in all three an inverted U-shape for all four variables. The control variables are similar to other samples, with men less unhappy although insignificant in the left-out equation. Education lowers unhappiness as does being married and in a job. Scandinavian countries, and especially Danes in the EQLS are happier and unhappiness is high in East European countries, Greece and Turkey. British people tend to feel left-out.

\section{Discussion}

There appears to be a midlife crisis. It appears in both happiness and unhappiness data. I add to the growing list of unhappiness variables that have an inverted U-shape in age with or without controls. I find an inverted happiness curve in fifteen measures of unhappiness including being in despair, anxious, sad, sleepless; lonely; tired; depressed, tense, under strain and more. I also found the inverted U-shape for two more general measures relating to the respondent's country and to the world. The unhappiness curve is found in every case with controls and without controls in the BRFSS for the US; the LFS and APS in the UK and the Eurobarometer. It is hard to find without controls using the ESS or EQLS (Appendix 1). ${ }^{13}$

\footnotetext{
${ }^{13}$ The inverted $\mathrm{U}$ can be seen in Appendix without controls in the EQLS for feeling left-out or tense but not for the other seven variables.
} 
So, what is going on? In Blanchflower and Oswald (2008) we suggested three possibilities. First, that individuals learn to adapt to their strengths and weaknesses, and in mid-life quell their infeasible aspirations. A second possibility is that a kind of comparison process is at work: I have seen school-friends die and come eventually to value my blessings during my remaining years. Third, it could be that cheerful people live systematically longer than the miserable, and that the well-being U-shape in age thus traces out in part a selection effect. In a recent paper O'Connor and Graham (2020) provide some recent supporting evidence for such a hypothesis and show that optimists in the US (based on the PSID) actually do live longer. They also report that while both women and blacks became more optimistic in the 70's due likely to rights improvements, the only group that began to decline in optimism were less than college educated whites (or less than high school in those days), precisely when the first wave of manufacturing declined happened.

Of note is that in the years since the Great Recession especially bad things seem to be happening to the prime age, and particularly those with less education, who are feeling left behind. In the UK real wages at the start of 2020 are about 4\% below what they were at the beginning of 2008 just before the Great Recession started. In the US the participation rate of prime age men ages 25-54 is still below what it was in January 2008 (82.8\% versus 83.3\%) despite an unemployment rate of $3.5 \%$. Female rates, in contrast, have returned. The underemployment rate, measured as the number of part-time for economic reasons as a percent of total employed, which Bell and Blanchflower (2019b) show to be the main determinant of weak wage growth is still above its prerecession lows.

A survey conducted by the Federal Reserve found that about $40 \%$ of adults said they would not be able to cover a $\$ 400$ unexpected expense with cash and would either not be able to pay or would do so by selling something or borrowing. ${ }^{14}$ At the same time wage and income inequality widens.

We know from happiness research that relative things matter. People compare themselves to others. Luttmer (2005) explored whether individuals feel worse when others around them earn more (2005). That is, do they care about their relative position? The answer was in the affirmative; higher earnings of neighbors are associated with lower levels of self-reported happiness. An increase in neighbors' earnings and a similarly sized decrease in own income, Luttmer found, have roughly the same negative effect on well-being.

The finding of a dip in well-being in midlife likely adds important support to the notion that being in one's forties and fifties exacerbates vulnerability to disadvantages and shocks. ${ }^{15}$ That is people with disabilities, less education, broken families, lost jobs and so on are likely also to get hit hardest by the effects of aging. Some might face downward spirals as age and life circumstances interact. Many will not be getting the social/emotional support they need, because midlife is the worst time to present vulnerability. They will be dealing with shame and isolation, in addition to the firstorder effects of whatever they are coping with in normal times at a midlife low is tough and made much harder when combined with a deep downturn and a slow and weak recovery.

\footnotetext{
${ }^{14}$ Report on the Economic Well-Being of U.S. Households in 2017, Reserve Board of Governors, Washington, D.C.

${ }^{15}$ I am grateful to Jonathan Rauch for these suggestions that he says create a 'toxic brew'.
} 
In the years since the Great Recession the resiliency of communities to soften economic and social shocks has diminished. The prime age with few skills were especially vulnerable and the social mores that protected them in the past had been slashed with the free society, market driven mantra mantra of individual rather than collective responsibility. The friendly societies were long gone. This combination of hurts proved deadly for many.

Clark and Heath (2015) argued that the Great Recession laid bare underlying social wounds and scars that were already, what they call "gradual evolution of disadvantage". It simply exposed underlying problems with deep roots in the long decades before. As Robert Putnam in his insightful book Bowling Alone revealed, there has been " $a$ steady withering of America's community bonds." The more integrated we are with our communities, Putnam notes, the less likely we are to experience colds, heart attacks, strokes, cancer, depression, and premature death of all sorts $(2000,327)$.

The lack of social cohesion made it harder for the weak and the vulnerable including those going through what looks like a very natural midlife nadir of happiness. Social cohesion matters for health. Socially isolated people are more likely to smoke, drink, overeat, and engage in other health-damaging behaviors. As a rough rule of thumb, Putnam notes, if you belong to no groups but decide to join one, you cut your risk of dying over the next year in half $(2000,331)$. Social support, Putnam notes, also lessens depression.

Beginning in the late 1960s, Putnam and his coauthors write in Better Together, Americans began to "join less, trust less, give less, vote less and schmooze less" (2003, 4). They go on to note that the more neighbors who know one another by name, the fewer crimes a neighborhood as a whole will suffer. A child born in a state whose residents volunteer, vote, and spend time with friends is less likely to be born underweight, less likely to drop out of school, and less likely to kill or be killed than the same child-no richer or poorer-born in another state whose residents do not (2003, 269). Social ties bind. Putnam notes that the longer a kid lives in a bad neighborhood the worse the effects $(2015,217)$.

Trust has broken down. The General Social Survey (GSS) has asked respondents every year since 1972 - 'Can people be trusted? In 1972 of those in prime age 55\% agreed. By 2018 the percent concurring had plummeted to 32\%. In the GSS respondents were asked "tell me which answer comes closest to how often you do the following things...spend a social evening with someone who lives in your neighborhood - almost every day; once or twice a week; several times a month; several times a year; about once a year and never? In 1974 when the question was first asked 22\% said 'never' compared with 33\% in 2018.

In its 2017 Global Attitudes Survey, Pew asked respondents in thirty-eight countries, developed and developing, about their well-being and their trust in their government. I am particularly interested in the responses to two questions:

Q1. "In general, would you say life in (survey country) today is better, worse, or about the same as it was fifty years ago for people like you?" 
The proportion saying that life was 'better" for people like you accounted less than half of respondents in France (34\%); Greece (28\%); Italy (24\%) the UK (49\%) and the USA (43\%). There were majorities in Australia (53\%); Canada (58\%); Germany (68\%), Japan (68\%); Netherlands (67\%), Spain (63\%) and Sweden (66\%). They were asked a follow-up question

Q2 When children today in (survey country) grow up, do you think they will be better off or worse off financially than their parents-better off; worse off; or the same?"

Only 38\% in the USA and Germany compared with 20\% in Japan 25\% in Australia, Canada and the UK, said "better off". The low was 9\% in France and the high 45\% in Sweden.

Communities appear to have been less resilient to the big changes that the Great Recession brought than they had been in the past. This may well be a function of the sheer size of the shock but also that in the recovery years since 2010 austerity undermined the ability of communities to absorb the hit. Public spending cuts in the UK for example decimated communities. Portugal, Ireland, Italy, Greece and Spain implemented tough austerity packages. As Mark Blyth has argued "that austerity simply doesn't work is the first reason why it's a dangerous idea. (2015, p.5)."

Research has suggested that rural communities in particular facing rapid economic, social and environmental change need to be resilient to maintain their community well-being. ${ }^{16}$ Graham and Pinto (2016) found that reported pain is higher in rural areas than in urban areas, where optimism about future life satisfaction is significantly lower. McCrea et al (2014) summarize the literature on community resiliency. The authors cite Magis (2010, p. 402) who described community resilience as, 'the existence, development, and engagement of community resources by community members to thrive in an environment characterized by change, uncertainty, unpredictability, and surprise.'

In many towns and communities around the world this resiliency seems to have broken down. The ties that bind have disappeared, and the social support networks and fabric are breaking under the strain. The removal of public social resources has made it hard for communities to hold themselves together. In the UK the government cut 20,000 police over the decade 2010-2020 including most community police. Local community, youth and recreation centers and libraries closed in the UK as a result of the massive spending cuts orchestrated in the name of growth, decimating communities who were unable to provide a social backstop to the left-behinds.

There have been dramatic increases in food bank use around the world which continues even with record low levels of unemployment. In the United States Bacon and Baker (2017) found that food banks served an estimated 46 million people in 2015. The CEO of the Trussell Trust, the UK's largest food bank provider, which gave 1.6m food parcels in between April 2018 and March 2019, has argued that he people coming to the food bank are often "embarrassed and ashamed, they don't want to be here", says Daphine Aikens. ${ }^{17}$ Want in the face of plenty. Austerity failed.

\footnotetext{
${ }^{16}$ The Rand Organization defines Community resilience as a measure of the sustained ability of a community to utilize available resources to respond to, withstand, and recover from adverse situations.

https://www.rand.org/topics/community-resilience.html
}

${ }^{17}$ By Sean Coughlan 'Food bank supplies help record numbers'. BBC, 25 ${ }^{\text {th }}$ April 2019. 
There is evidence from the CDC that the death rate in rural areas from the five leading causes of death-heart disease, cancer, unintentional injury, chronic lower respiratory disease, and strokeis much higher than in urban areas. ${ }^{18}$ Moy and coauthors (2017) note that it is well known that residents in rural areas have higher rates of health risk factors for the leading causes of death, including factors such as cigarette smoking, obesity, physical inactivity during leisure time, and not wearing seatbelts. They also tend to have less access to health care and preventive services. The authors examine "excess death," which the CDC defines as deaths among persons less than 80 years old over the number that would be expected if the age-specific death rates of the three states with the lowest rates (i.e., benchmark states) occurred across all states. They find that approximately half of deaths among persons less than 80 years old from unintentional injury (57.5\%) in nonmetropolitan areas were potentially excess deaths, compared with 39.2 percent in metropolitan areas. Over the period 1999-2014 deaths from unintentional injury rose in metropolitan and nonmetropolitan areas, and in all years, they were approximately 50 percent higher in rural areas than urban areas.

Garcia et al. (2017) suggest that several factors explain the wide gap in rural-urban death rates from unintentional injuries. First, unintentional injury burden is higher in rural areas because of severe trauma associated with high-speed motor vehicle traffic-related deaths. Second, rates of opioid analgesic misuse and overdose death are highest among poor and rural populations. Third, behavioral factors (e.g., alcohol-impaired driving, seatbelt use, and opioid prescribing) contribute to higher injury rates in rural areas. Fourth, access to treatment for trauma and drug poisoning is often delayed when the injury occurs in rural areas. For life-threatening injury, higher survival is associated with rapid emergency treatment. Because of the geographic distance involved, emergency medical service (EMS) providers who operate ambulances take longer to reach injured or poisoned patients in rural areas. Moreover, the authors note, ambulatory transport to the optimal treatment facility also can take longer because of increased distance to the treatment facility. Most life-threatening trauma is best treated in advanced trauma centers, which are usually located in urban areas; care at these centers has been associated with 25 percent lower mortality (Mackenzie 2006).

Hedegaard, Curtin, and Warner (2018) showed that the age-adjusted suicide rate for urban counties in 2017 was 16 percent higher than the rate in 1999, whereas in rural counties in 2017 it was 53 percent higher. By 2017 the suicide rate in rural counties (20 per 100,000) was nearly double that of urban counties (11.1). Mack et al (2017) found that rug-overdose death rates (per 100,000 people) for metropolitan areas were higher than in nonmetropolitan areas in 1999 (6.4 versus 4.0); however, the rates converged in 2004, and by 2015, the nonmetropolitan rate (17.0) was slightly higher than the metropolitan rate (16.2). Folks in rural areas, whose health care has been left behind, voted for Trump.

The less educated in particular feel insecure as we enter the third decade of the twenty-first century. Areas that were left behind voted for Trump and Brexit (Blanchflower, 2019). In both instances the votes for change were positively correlated with the unemployment rate, low life expectancy,

https://www.bbc.com/news/education-48037122

${ }^{18}$ This section draws heavily on Blanchflower, 2019, pp. 234-236 
drug use, the smoking rate, the obesity rate and how poor the area was. Similarly, old Labour strongholds like Bolsover and Wakefield voted in the recent General Election in the UK for Boris Johnson to 'Get Brexit Done. A recent paper by Fetzer (2018) concluded that the onset of austerity in the UK in 2010 directly contributed to the Brexit vote. His findings suggest that the EU referendum could well have resulted in a Remain victory had it not been for a range of austerityinduced welfare reforms. These reforms, Fetzer suggests, "activated existing economic grievances” $(2018,1)$.

There are populist movements around the world responding to the burgeoning discontent. Eatwell and Goodwin have explained the allure of populism succinctly: "Those with fewer qualifications and more traditionalist values are more alarmed about how their societies are changing: they fear the eventual destruction of their community and identity, they believe that both they and their group are losing out, and distrust their increasingly distant representatives. National populists spoke to these voters, albeit in ways that many dislike. For the first time in years their supporters now feel they have an agency in the debate" $(2018,275)$.

People are struggling. Those in middle age in the years since 2008 were most vulnerable to a once in a generation financial shock especially if they were poor and with low levels of education. The crisis suddenly created frailty in downtrodden communities which simply exposed underlying problems with deep roots in the long decades before. It seems it is normal to have a midlife dip in well-being, but for many, especially those with the least skills, with little social support and few if any savings, that was too much to bear when a giant downturn came along. Many lost their homes.

Manufacturing jobs moved abroad; coal jobs disappeared into the ether. Such poorly paid jobs as were available had insufficient hours and so incomes remained low, while so many others - the exam taking classes - were doing fine. Austerity made matters worse as local community services were gutted and were less resilient than in the past to a downturn. Notably there hadn't been a scale this big for a generation and people and communities were unprepared. The social backstops built up slowly over generations failed.

Being middle-aged, especially with low levels of education, is tough these days. 


\section{References}

Arnade, C. (2019), Dignity. Seeking Respect in Back Row America, Penguin, Random House

Bacon, C.M. and A. Baker (2017), 'The rise of food banks and the challenge of matching food assistance with potential need: towards a spatially specific, rapid assessment approach,' Agriculture and Human Values, December, 34(4,) pp. 899-919.

Bell, D.N.F. and D.G. Blanchflower (2019), 'The well-being of the overemployed and the underemployed and the rise in depression in the UK', Journal of Economic Behavior and Organization, 161, May, pp. 180-196.

Beveridge, W.H. (1960), Full Employment in a Free Society. A Report, Routledge, NY first published in 1944.

Blanchflower, D.G. (2019), Not Working: Where Have All the Good Jobs Gone? Princeton University Press, Princeton, NJ.

Blanchflower, D.G. (2020), ' Is happiness U-shaped everywhere? Age and subjective well-being in 132 countries,', working paper.

Blanchflower D.G. (2009), 'International evidence on well-being' in Measuring the Subjective Well-Being of Nations: National Accounts of Time Use and Well-Being edited by Alan B. Krueger, editor (p. 155 - 226), NBER and University of Chicago Press.

Blanchflower, D.G. and, A.J. Oswald (2020), 'The rise in despair in the United States', under review.

Blanchflower, D.G. and, A.J. Oswald (2019), 'Unhappiness and pain in Modern America: a review essay, and further evidence, on Carol Graham's Happiness for All?', Journal of Economic Literature, June, 57(2), pp. 385-402.

Blanchflower, D.G. and, A.J. Oswald (2016), 'Anti-depressants and age: a new form of evidence for U-shaped well-being through life', Journal of Economic Behavior and Organization, 127, pp. 46-58.

Blanchflower, D.G. and, A.J. Oswald (2009), 'The U-shape without controls: A response to Glenn', Social Science and Medicine, 69, pp. 486-488.

Blanchflower, D.G. and, A.J. Oswald (2008), 'Is well-being U-shaped over the life cycle?' Social Science and Medicine, 66, pp. 1733-1749.

Blanchflower, D.G. and, A.J. Oswald (2004a), 'Money, sex and happiness: an empirical study,' Scandinavian Journal of Economics, 106(3), pp. 393-415.

Blanchflower, D.G. and, A.J. Oswald (2004b), 'Well-being over time in Britain and the USA,' Journal of Public Economics, 88(7-8), July, pp. 1359-1386. 
Blyth, M. (2015), Austerity. The History of a Dangerous Idea, Oxford University Press, Oxford.

Carpenter, C.S., C.B. McClellan, and D.I. Rees (2017), 'Economic conditions, illicit drug use, and substance use disorders in the United States', Journal of Health Economics, 52(C), pp. 63-73.

Case, A., and A. Deaton (2015), 'Rising morbidity and mortality in midlife among white nonHispanic Americans in the 21st century,' Proceedings of the National Academy of Sciences of the USA, 112(49), pp. 15078-15083.

Case, A., and A. Deaton (2017), 'Mortality and morbidity in the 21st century,' Brookings Papers on Economic Activity, Spring, pp. 397-476.

Clark, T. and A. Heath (2015), Hard Times: Inequality, Recession, Aftermath, New Haven and London: Yale University Press.

Eatwell R. and M. Goodwin, (2018), National Populism: The Revolt Against Liberal Democracy, London, Pelican Books.

Fetzer, T. (2019), 'Did austerity cause Brexit?', American Economic Review, 109(11), November, pp. 3849-3886,

Garcia, M.C., M. Faul, G. Massetti, C.C. Thomas, Y. Hong, U. Bauer and M.F. Iademarco (2017), 'Reducing potentially excess deaths from the five leading causes of death in the rural United States', Morbidity and Mortality Weekly Report Surveillance Summaries, 66(2), pp. 1-7.

Giuntella, O., S. McManus, R. Mujcic, A. J. Oswald, N. Powdthavee, A. Tohamy (2019), 'Why is there so much midlife distress in affluent nations?', Working Paper April.

Glenn, N. (2009), 'Is the apparent U-shape of well-being over the life course a result of inappropriate use of control variables? A commentary on Blanchflower and Oswald (66:8, 2008, 1733-1749),' Social Science and Medicine, 69(4), 481-485.

Graham, C., and S. Pinto (2016), 'Unhappiness in America: desperation in white towns, resilience and diversity in the cities', Brookings, September 29.

Graham, C. and J. R. Pozuelo (2017), 'Happiness, stress, and age: how the U curve varies across people and places', Journal of Population Economics, 30, pp.225-264.

Hedegaard, H., S. C. Curtin, and M. Warner (2018), 'Suicide mortality in the United States, 19992017', Centers for Disease Control and Prevention, NCHS Data Brief No. 330, November.

Hedegaard, H., A.M. Miniño and M. Warner (2018), 'Drug overdose deaths in the United States, 1999-2017', NCHS Data Brief No. 329 November. 
Institute of Medicine of the National Academy of Sciences (2011), 'Relieving pain in America: a blueprint for transforming prevention, core, education and research', Washington, DC: National Academies Press.

Krueger, A.B. (2017), 'Where have all the workers gone? An inquiry into the decline of the U.S. labor force participation rate.', Brookings Papers on Economic Activity, Fall, pp.1-66.

Lewis R.A., N.H. Williams, A.J. Sutton, K. Burton, N.U. Din, H.E. Matar, M. Hendry, C. Phillips, S. Nafees, D. Fitzsimmons, I. Rickard and C. Wilkinson (2015), 'Comparative clinical effectiveness of management strategies for sciatica: systematic review and network metaanalyses', Spine Journal, June 1;15(6), pp. 1461-1477.

Luttmer, E. F. P. (2005), 'Neighbors as negatives: relative earnings and well-being', Quarterly Journal of Economics, 120 (3), pp. 963-1002.

Mack, K.A.C., C.M. Jones and M.E. Ballesteros, (2017), 'Illicit drug use disorders, and drug overdose deaths in metropolitan and nonmetropolitan areas - United States', Morbidity and Mortality Weekly Report Surveillance Summaries 66(19), pp. 1-12.

MacKenzie, E. J., F. P. Rivara, G. J. Jurkovich, et all (2006), 'A national evaluation of the effect of trauma-center care on mortality', New England Journal of Medicine, 354., pp. 366-78.

Magis, K. (2010), 'Community resilience: an indicator of social sustainability', Society and Natural Resources, 23(5), pp. 401-416.

McCrea, R., A. Walton and R. Leonard (2014), 'A conceptual framework for investigating community wellbeing and resilience', Rural Society, 23(3), pp. 270-282.

Moy, E., C.G. Macarena B. Bastian, L. M. Rossen, D.D. Ingram, M. Faul, G.M. Massetti, C.C. Thomas, Y. Hong, P.W. Yoon and M.F. Iademarco (2017), 'Leading causes of death in nonmetropolitan and metropolitan areas - United States, 1999-2014', Morbidity and Mortality Weekly Report Surveillance Summaries, 66(1), pp. 1-8.

Novosad, P. and C. Rafkin (2019), 'Mortality change among less educated Americans', working paper.

O’Connor, K.J. and C. Graham (20190), 'Longer, more optimistic, lives: historic optimism and life expectancy in the United States', Journal of Economic Behavior and Organization, 168, December, pp. 374-392.

ONS (2018), 'Changing trends in mortality: an international comparison: 2000 to 2016', $7^{\text {th }}$ August. https://www.ons.gov.uk/peoplepopulationandcommunity/birthsdeathsandmarriages/lifeexpectanc ies/articles/changingtrendsinmortalityaninternationalcomparison/2000to2016

Pratt, L. A., and D. J. Brody (2014), 'Depression in the U.S. household population, 2009-2012', NCHS Data Brief No. 172, December. 
Putnam, R.D. (2000), Bowling Alone, Simon Schuster.

Putnam, R.D., L.M. Feldstein and D. Cohen (2003), Better Together. Restoring the American Community, Simon Schuster.

Quinones, S. (2015), Dreamland, Bloomsbury Press

Rauch, J. (2018), The U-shape of Happiness. New York: St. Martin’s Press.

Scholl, L., P. Seth, M. Kariisa, N. Wilson and G. Baldwin (2019), 'Drug and opioid-involved overdose deaths - United States, 2013-2017', Morbidity and Mortality Weekly R Report, 67, pp. 1419-1427.

Woolf, S.H. and H. Schoomaker (2019), 'Life expectancy and mortality rates in the United States, 1959-2017', Journal of the American Medical Association, November 26, 322(20), pp. 1996-2016. 
Table 1. Incidence of Chronic Depression in the EU28 \%

$\begin{array}{lrrrrrrr} & \text { Total } & 15-24 & 25-34 & 35-44 & 45-54 & 55-64 & 65-74 \\ \text { EU28 } & 7.1 & 4.0 & 5.3 & 5.9 & 8.3 & 9.3 & 7.7 \\ \text { Belgium } & 6.7 & 1.0 & 3.4 & 6.8 & 8.8 & 10.0 & 7.3 \\ \text { Denmark } & 8.0 & 8.3 & 8.6 & 9.8 & 7.4 & 8.1 & 5.8 \\ \text { Finland } & 10.5 & 10.8 & 13.5 & 9.9 & 9.3 & 10.1 & 6.5 \\ \text { France } & 5.9 & 2.7 & 4.2 & 5.9 & 7.1 & 7.7 & 4.8 \\ \text { Germany } & 10.6 & 8.7 & 9.9 & 10.0 & 12.5 & 13.7 & 8.1 \\ \text { Hungary } & 4.9 & 1.1 & 2.1 & 2.6 & 6.1 & 8.1 & 6.9 \\ \text { Ireland } & 12.1 & 12.4 & 10.1 & 11.0 & 12.5 & 17.0 & 12.3 \\ \text { Luxembourg } & 9.5 & 6.6 & 8.4 & 9.4 & 12.4 & 11.7 & 6.6 \\ \text { Malta } & 5.4 & 2.1 & 1.8 & 3.5 & 6.6 & 9.8 & 6.9 \\ \text { Netherlands } & 7.9 & 6.1 & 8.0 & 8.5 & 10.0 & 8.2 & 5.7 \\ \text { Norway } & 6.9 & 5.6 & 7.5 & 8.3 & 6.1 & 8.7 & 5.4 \\ \text { Poland } & 4.2 & 1.2 & 2.2 & 3.0 & 4.9 & 6.3 & 5.7 \\ \text { Sweden } & 9.6 & 10.3 & 13.1 & 10.0 & 11.4 & 9.7 & 5.2 \\ \text { Turkey } & 11.0 & 6.6 & 9.5 & 12.1 & 15.2 & 13.2 & 12.7 \\ \text { United Kingdom } & 8.9 & 6.7 & 8.3 & 8.5 & 11.3 & 11.6 & 7.6\end{array}$

Table 2.: Suicide rates, 2000 - 2016. Source: OECD

$\begin{array}{lrr}\text { Location } \mathbf{} & 2000 & \boldsymbol{\nabla} 2016 \\ \text { Australia } & 12.6 & 11.9 \\ \text { Austria } & 19.4 & 12.2 \\ \text { Belgium } & 20.5 & 15.9 \\ \text { Canada } & 11.5 & 11.8 \\ \text { Denmark } & 13.5 & 9.4 \\ \text { Finland } & 22.1 & 13.9 \\ \text { France } & 18.2 & 13.1 \\ \text { Germany } & 12.8 & 10.2 \\ \text { Ireland } & 12.3 & 9.3 \\ \text { Italy } & 6.7 & 5.7 \\ \text { Japan } & 22.3 & 15.2 \\ \text { Netherlands } & 9.4 & 10.5 \\ \text { Norway } & 12.3 & 11.6 \\ \text { Spain } & 8.1 & 6.8 \\ \text { Sweden } & 12.4 & 11.1 \\ \text { Switzerland } & 18.7 & 11.2 \\ \text { United Kingdom } & 7.0 & 7.3 \\ \text { United States } & 10.8 & 13.9\end{array}$

"Deaths deliberately initiated and performed by a person in the full knowledge or expectation of its fatal outcome."

https://data.oecd.org/healthstat/suicide-rates.htm 
Table 3. United States. BRFSS Despair, 1993-2018

(1)

(2)

Age $20-29$
Age $30-39$
Age $40-49$
Age 50-59
Age 60-69
Age $70-79$
Age $>=80$

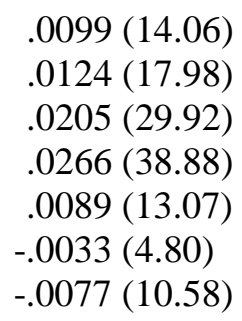

.0099 (14.06)

.0124 (17.98)

.0205 (29.92)

$.0266(38.88)$

.0089 (13.07)

$-.0033(4.80)$

-.0077 (10.58)

\begin{abstract}
.0207 (28.72)
$.0248(33.60)$

$.0263(35.58)$

$.0210(28.37)$

$.0001(0.10)$

$-.0117(14.80)$

-.0217 (26.23)
\end{abstract}

Cohort 1930-40

Cohort 1940-50

Cohort 1950-60

Cohort 1960-70

Cohort 1970-80

Cohort 1980-90

Cohort 1990-2000

Male

Black

Asians

Native Americans

Other races

Hispanics

$\begin{array}{cc}-.0104(62.16) & -.0104(62.16) \\ & -.0142(47.51) \\ & -.0130(24.29) \\ & .0080(11.77) \\ & .0192(34.86) \\ & -.0073(23.34)\end{array}$

\section{Constant}

Labor force dummies

Education dummies

Marital status dummies

Year dummies

Adjusted R ${ }^{2}$

$\mathrm{N}$

T-statistics in parentheses.

$\begin{array}{cc}\text { No } & \text { Yes } \\ \text { No } & \text { Yes } \\ \text { No } & \text { Yes } \\ \text { Yes } & \text { Yes } \\ & \\ .0258 & .0227 \\ .0022 & .0554 \\ 7,689,277 & 7,682,918\end{array}$

Notes: despair $=1$ if $\#$ not good mental health days $=30$, zero otherwise.
(3)

$-.0104(61.91)$

$-.0142(47.59)$

$-.0130(24.30)$

$.0079(11.70)$

$.0192(34.77)$

$-.0073(23.39)$

$$
\begin{aligned}
& \text { Yes } \\
& \text { Yes } \\
& \text { Yes } \\
& \text { Yes }
\end{aligned}
$$

.0112
.0555
$7,682,917$

(4)

HS and below

$.0488(12.84)$

$0666(15.07)$

$.0913(17.90)$

$.0859(14.91)$

$.0430(6.63)$

$0260(3.60)$

.0096 (1.26)

-.0035 (1.87)

.0095 (3.40)

0355 (9.21)

.0475 (9.91)

$.0636(10.75)$

.0785 (11.20)

.0839 (9.93)

-.0219 (22.04)

(5)

Some college .0212 ()5.38) .0225 (5.01) .0334 (6.42) .0287 (4.78) $-.0027(0.40)$ -.0107 (1.38) -.0160 (1.90)

-.0047 (1.77) $.0001(0.02)$ .0087 (1.89) .0076 (1.8) $.0006(0.09)$ $.0019(0.25)$ .0039 (0.43) -.0118 (10.41)

$-.0004(0.13)$ $.0291(13.05)$ .0488 (20.62)
Yes
Yes
Yes

Yes

Yes
$-.0559$
.0735
431,843

0403

302,901 
Table 4. Main health problems in the UK, LFS 2014-2018.

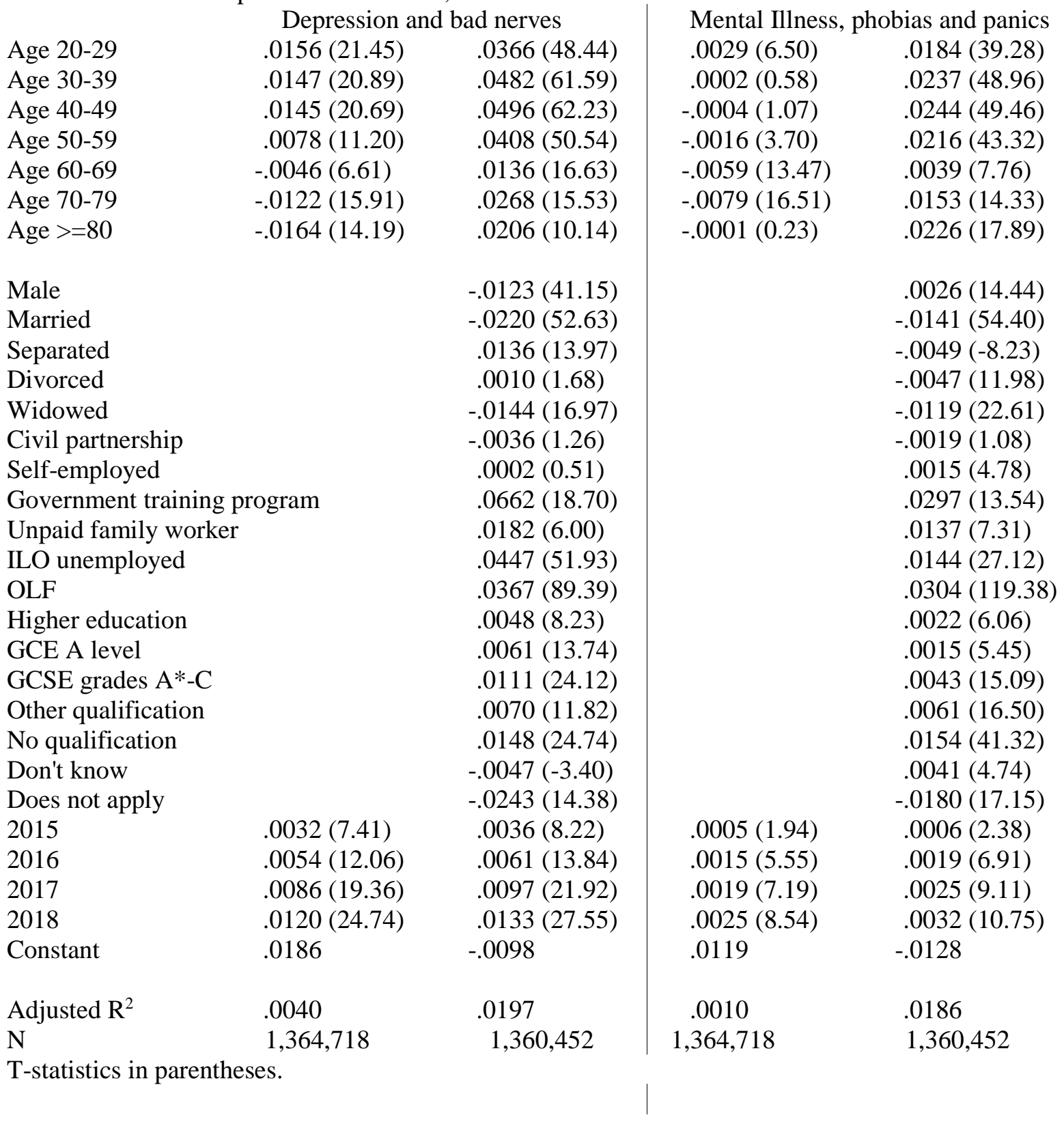


Table 5. Six GHQ Unhappiness Measures, 2001.

Lost much sleep over worry Feeling unhappy and depressed

$\begin{array}{lll}\text { Age 20-29 } & .2057(6.98) & .1393(4.17) \\ \text { Age 30-39 } & .3217(11.11) & .2304(5.98) \\ \text { Age 40-49 } & .3937(13.25) & .2905(7.28) \\ \text { Age 50-59 } & .3786(12.56) & .2570(6.26 \\ \text { Age 60-69 } & .2725(8.92) & .1408(3.13) \\ \text { Age 70-79 } & .2291(6.89) & .0847(1.72) \\ \text { Age }>=80 & .1921(4.18) & .0149(0.25) \\ \text { Controls } & \text { No } & \text { Yes } \\ \text { Constant } & .6257 & .7155 \\ \text { Adjusted R } & .0531 & .0744 \\ \mathrm{~N} & 15,782 & 15,779\end{array}$

Could not overcome difficulties

Age 20-29

Age 30-39

Age 40-49

Age 50-59

Age 60-69

Age 70-79

Age $>=80$

Controls

Constant

Adjusted R ${ }^{2}$

$\mathrm{N}$

$\begin{array}{cc}.1217(4.46) & .1136(3.69) \\ .1409(5.25) & .1419(3.99) \\ .2007(7.29) & .1842(5.01) \\ .1531(5.48) & .1051(2.78) \\ .0663(2.34) & -.0301(0.73) \\ .0865(2.80) & -.0419(0.92) \\ .1138(2.67) & -.0523(0.95) \\ \text { No } & \text { Yes } \\ .5620 & .6779 \\ .0317 & .0728\end{array}$

$.1629(5.70) \quad .1445(4.49)$

$.1961(6.99) \quad .1959(5.28)$

$.2684(9.32) \quad .2554(6.65)$

$.2633(9.01) \quad .2224(5.63)$

$.1634(5.52) \quad .0745(1.72)$

$.2053(6.37) \quad .0717(1.51)$

.1658 (3.73) $\quad-.0287(0.50)$

\begin{tabular}{cc}
\multicolumn{1}{c}{ No } & Yes \\
.5596 & .6562 \\
.0298 & .0743 \\
15,789 & 15,786
\end{tabular}

Constantly under strain

$.2001(7.09) \quad$.2024 (6.27)

$.2460(8.88) \quad .2504(6.72)$

$.2654(9.33) \quad .2613(6.78)$

$.2072(7.18) \quad .1972(4.98)$

$-.0002(0.01) \quad .0155(0.36)$

$-.0500(1.57) \quad-.0394(0.83)$

$-.0974(2.21) \quad-.1188(2.06)$

$\begin{array}{cc}\text { No } & \text { Yes } \\ .6057 & .6101 \\ .0479 & .0651 \\ 15,756 & 15,753\end{array}$

Losing confidence in yourself

$.1146(4.50) \quad .1206(4.18)$

$.1276(5.10) \quad .1579(4.75)$

$.1802(7.02) \quad .1993(5.79)$

$.1439(5.52) \quad .1339(3.78)$

$.0746(2.82) \quad .0064(0.16)$

$.1123(3.90) \quad .0107(0.25)$

$.1219(3.06) \quad-.0172(0.33)$

$\begin{array}{cc}\text { No } & \text { Yes } \\ .4643 & .5091 \\ .0199 & .0564 \\ 15,754 & 15,751\end{array}$

Thinking yourself a worthless person

$\begin{array}{cc}.0728(3.18) & .0473(1.82) \\ .0930(4.13) & .0707(2.36) \\ .1564(6.77) & .1231(3.96) \\ .1347(5.75) & .0811(2.54) \\ .0596(2.51) & -.0224(0.64) \\ .0945(3.65) & -.0077(0.20) \\ .1611(4.50) & -.0320(0.69) \\ \text { No } & \text { Yes } \\ .2782 & .3668 \\ .0263 & .0593 \\ 15,754 & 15,711\end{array}$

Controls are education; marital and labor force status and 14 country dummies -Austria; Belgium; Denmark; Finland; France; Germany; Greece; Ireland; Italy; Luxembourg; Netherlands; Portugal; Spain; Sweden and UK. Source: Eurobarometer \#56.1, Sept.- Oct. 2001.

Have you recently:

Q2. Lost much sleep over worry?

Q3. Felt constantly under strain?

Q4. Felt you could not overcome your difficulties?

Q5. Been feeling unhappy and depressed?

Q6. Been losing confidence in yourself?

Q7. Been thinking of yourself as a worthless person? 
Table 6. Anxiety in the UK, APS 2016-2018 with age $<80$

$\begin{array}{lcc} & \text { No controls } & \text { With controls } \\ \text { Age 20-29 } & .1394(2.70) & .3075(5.95) \\ \text { Age 30-39 } & .1618(3.21) & .4815(9.39) \\ \text { Age 40-49 } & .2564(5.11) & .6191(12.02) \\ \text { Age 50-59 } & .2542(5.09) & .5990(11.63 \\ \text { Age 60-69 } & -.0644(1.29) & .0767(1.48) \\ \text { Age 70-79 } & -.2451(4.86) & .0047(0.07) \\ 2017 & -.0064(0.45) & -.0008(0.06) \\ 2018 & -.0530(3.50) & -.0524(3.50) \\ & & \\ \text { Male } & & -.3307(8.42) \\ \text { Higher education } & & -.2211(10.14) \\ \text { GCE A level } & & -.1595(9.15) \\ \text { GCSE grades A*-C } & & -.1599(8.88) \\ \text { Other qualification } & & -.0771(3.16) \\ \text { No qualification } & & .1103(4.65) \\ \text { Married } & & -.3805(24.39) \\ \text { Married separated } & & .2231(6.61) \\ \text { Divorced } & & .0085(0.39) \\ \text { Widowed } & & -.0794(2.78) \\ \text { Civil partnership } & & .0200(0.17) \\ \text { Self-employed } & & .0068(0.33) \\ \text { Government employee } & & .7675(4.40) \\ \text { Unpaid family worker } & & .2289(2.26) \\ \text { ILO unemployed } & & .6438(17.63) \\ \text { OLF } & & .5268(33.43) \\ \text { Constant } & & 2.78337 \\ \text { Adjusted R } & & \\ \text { N } & & \\ \end{array}$

Excluded categories age 16-19, employee, white, degree, never married, age<20.

Q8. Anxious (1). - On a scale where nought is 'not at all anxious' and 10 is 'completely anxious', overall, how anxious did you feel yesterday? 
Table 7. Unhappiness. European Social Survey (sweeps 3 and 6)

\begin{tabular}{|c|c|c|c|c|}
\hline & Anxious & Feel a failure & Not hopeful & Life getting wors \\
\hline Age 20-29 & .0855 (6.23) & $.0480(2.39)$ & $.0892(4.48)$ & $.0640(3.46)$ \\
\hline Age 30-39 & .1212 (7.89) & .1796 (7.98) & $1527(6.85)$ & 1206 (5.84) \\
\hline Age 40-49 & $.1323(8.47)$ & $.1794(7.84)$ & $.1914(8.44)$ & $.1759(8.38)$ \\
\hline Age 50-59 & $.1237(7.81)$ & $.1611(6.95)$ & .2021 (8.79) & 1954 (9.18) \\
\hline Age 60-69 & $.0710(4.19)$ & $.0478(1.93)$ & .1555 (6.32) & 1584 (6.96) \\
\hline Age 70-79 & $.0808(4.40)$ & $-.0190(0.71)$ & $.1839(6.88)$ & $.1017(4.12)$ \\
\hline Age $>=80$ & $.0213(1.03)$ & $-.1260(4.15)$ & .1324 (4.39) & $.0468(1.68)$ \\
\hline Male & -.1149 (23.71) & $-.1658(23.36)$ & $-.1389(19.76)$ & $-.0739(11.43)$ \\
\hline Years education & $-.0097(15.01)$ & $-.0145(15.30)$ & $-.0264(28.18)$ & $-.0252(29.21)$ \\
\hline Separated & $.1521(6.44)$ & $.2219(6.39)$ & $.1677(4.90)$ & $.0985(3.11)$ \\
\hline Divorced & $.0804(9.54)$ & $.1447(11.72)$ & $.0947(7.75)$ & $.0956(8.50)$ \\
\hline Widowed & $.1610(17.76)$ & $.0864(6.50)$ & $.1382(10.48)$ & $.0504(4.16)$ \\
\hline Never married & $.0288(4.06)$ & $1662(16.00)$ & $.0834(8.11)$ & $.0309(3.26)$ \\
\hline Civil partnership & $.0462(2.23)$ & $.0925(3.04)$ & $.0354(1.18)$ & $.0344(1.24)$ \\
\hline Education & .0399 (3.31) & $.0670(3.80)$ & $.0253(1.45)$ & $-.1011(6.25)$ \\
\hline Unemployed looking & $1772(14.84)$ & .3052 (17.43) & $.2682(15.49)$ & $.2808(17.65)$ \\
\hline Unemployed, not looking & 1839 (10.15) & $.2584(9.71)$ & .3179 (12.05) & $.2249(9.31)$ \\
\hline Permanently sick & $.4562(29.81)$ & $.4845(21.56)$ & $.6164(27.75)$ & .2865 (13.97) \\
\hline Retired & $.0857(9.11)$ & $.0830(6.02)$ & .1666 (12.19) & $.1100(8.76)$ \\
\hline Community/military serv. & $.1690(2.77)$ & $.2726(3.04)$ & $.0805(0.89)$ & $.0627(0.75)$ \\
\hline Housework & $.0412(4.57)$ & $.0833(6.30)$ & $.1022(7.81)$ & $.0776(6.43)$ \\
\hline Other lmkt & .1052 (4.49) & $.1723(5.01)$ & $.1381(4.06)$ & $.0735(2.34)$ \\
\hline Sweep 6 & $-.0016(0.33)$ & $-.0737(10.21)$ & $-.1150(16.08)$ & $.2936(44.58)$ \\
\hline _cons & 1.6328 & 2.1839 & 2.8693 & 3.4566 \\
\hline Adjusted $\mathrm{R}^{2}$ & .1571 & .1291 & .0856 & .2501 \\
\hline $\mathrm{N}$ & 90986 & 90941 & 90545 & 90161 \\
\hline
\end{tabular}

Equations include 27 country dummies. T-statistics in parentheses.

Q9. Felt anxious, how often the past week? (3 \& 6)

All of the time $=1$; Most of the time $=2$; More than half of the time=3; Less than half of the time $=4$; Some of the time $=5 ;$ At no time $=6$ ?

Q10. At times, feel a failure? (3 \& 6)

Disagree strongly=1; Disagree=2; Neither agree nor disagree=3; Agree $=4$ and Agree strongly $=5$

Q11. Hard to be hopeful about the future of the world (3 \& 6)

Disagree strongly=1; Disagree=2; Neither agree nor disagree=3; Agree $=4$ and Agree strongly $=5$

Q12. For most people in country life is getting worse (3 \& 6)

Disagree strongly=1; Disagree=2; Neither agree nor disagree=3; Agree $=4$ and Agree strongly $=5$ 
Table 8. Unhappiness - European Social Survey (sweeps 3, 6 and 7)

$\begin{array}{lcccc} & \text { Lonely } & \text { Sad } & \text { Depressed } & \text { Restless sleep } \\ \text { Age 20-29 } & .0892(7.95) & .0461(4.23) & .0689(6.31) & .1121(8.20) \\ \text { Age 30-39 } & .1390(11.06) & .0802(6.56) & .1102(9.01) & .1533(10.00) \\ \text { Age 40-49 } & .1578(12.32) & .1121(8.99) & .1346(10.80) & .1726(11.06) \\ \text { Age 50-59 } & .1567(12.09) & .1126(8.93) & .1330(10.54) & .2201(13.94) \\ \text { Age 60-69 } & .1139(8.24) & .0643(4.78) & .0727(5.41) & .1727(10.25) \\ \text { Age 70-79 } & .1291(8.59) & .0751(5.14) & .0942(6.44) & .1966(10.73) \\ \text { Age }>=80 & .1790(10.67) & .0735(4.50) & .1072(6.56) & .1531(7.48) \\ & & & & \\ \text { Male } & -.0432(11.02) & -.1384(36.22) & -.1171(30.64) & -.1587(33.16) \\ \text { Years education } & -.0115(21.93) & -.0104(20.28) & -.0143(27.82) & -.0118(18.42) \\ \text { Separated } & .4460(21.70) & .2643(13.22) & .2311(11.55) & .1735(6.93) \\ \text { Divorced } & .3503(51.95) & .1440(21.94) & .1237(18.85) & .0841(10.24) \\ \text { Widowed } & .5986(80.14) & .2858(39.31) & .1898(26.07) & .1605(17.64) \\ \text { Never married } & .2364(41.27) & .0789(14.16) & .0665(11.93) & .0247(3.55) \\ \text { Civil partnership } & .0713(4.03) & .0397(2.31) & .0253(1.47) & .0765(3.55) \\ \text { Education } & .0025(0.26) & .0339(3.57) & .0236(2.48) & .0153(1.32) \\ \text { Unemployed looking } & .1654(16.87) & .2138(22.42) & .2478(25.96) & .1636(13.69) \\ \text { Unemployed, not looking } & .2255(15.07) & .2157(14.84) & .2533(17.38) & .1789(9.84) \\ \text { Permanently sick } & .3995(32.48) & .4651(38.89) & .5869(49.01) & .6180(41.28) \\ \text { Retired } & .0888(11.57) & .0983(13.16) & .1089(14.58) & .1309(14.00) \\ \text { Community/military serv. } & .1023(2.05) & .0947(1.96) & .1402(2.89) & .2271(3.75) \\ \text { Housework } & .0774(10.27) & .0747(10.19) & .0787(10.73) & .1240(13.51) \\ \text { Other lmkt } & .1195(6.30) & .1515(8.22) & .1583(8.58) & .1420(6.15) \\ \text { Sweep 6 } & -.0399(8.55) & -.0309(6.82) & -.0495(10.89) & -.0292(5.15) \\ \text { Sweep 7 } & -.0535(10.63) & -.0423(8.65) & -.0788(16.07) & -.0114(1.86) \\ \text { cons } & 1.2646 & 1.4979 & 1.4988 & 1.7017 \\ \text { Adjusted R }{ }^{2} & .1498 & .1293 & .1205 & .0689 \\ \text { N } & 129,953 & 129,985 & 129,914 & 130,225 \\ \text { Exclud: } & & & \end{array}$

Excluded: sweep 3; married, employed

Equations include 27 country dummies. T-statistics in parentheses.

Q13. Felt lonely last week. None or almost none of the time=1; some of the time=2; most of the time $=3$; all or almost all of the time $=4$ ?

Q14. Felt sad, how often over the past week? None or almost none of the time=1; some of the time $=2$; most of the time $=3$; all or almost all of the time $=4$ ?

Q15. Felt depressed how often past week? None or almost none of the time=1; some of the time $=2$; most of the time $=3$; all or almost all of the time $=4$ ?

Q16. Sleep was restless how often past week? None or almost none of the time $=1$; some of the time=2; most of the time=3; all or almost all of the time $=4$ ? 
Table 9. EQLS 2007-2016, waves 2-4

$\begin{array}{lcccc} & \text { Lonely } & \text { Downhearted } & \text { Left out } & \text { Tense } \\ \text { Age 20-29 } & .1590(4.68) & .1943(5.84) & .0350(1.62) & .1228(3.36) \\ \text { Age 30-39 } & .2883(7.83) & .3217(8.93) & .1026(4.37) & .2403(6.06) \\ \text { Age 40-49 } & .3123(8.42) & .3568(9.82) & .1029(4.35) & .2605(6.52) \\ \text { Age 50-59 } & .2979(7.98) & .3483(9.52) & .0642(2.69) & .2079(5.17) \\ \text { Age 60-69 } & .1558(3.94) & .2042(5.27) & -.0450(1.78) & -.0015(0.04) \\ \text { Age 70-79 } & .2319(5.55) & .2716(6.63) & -.0300(1.12) & -.0142(0.32) \\ \text { Age }>=80 & .2786(6.17) & .2451(5.54) & .0189(0.65) & -.1301(2.68) \\ & & & & \\ \text { Male } & -.0632(6.78) & -.1302(14.27) & .0113(1.84) & -.1300(12.98) \\ \text { Secondary } & -.2303(14.83) & -.2574(16.92) & -.1290(12.90) & -.1645(9.85) \\ \text { Tertiary } & -.3700(21.25) & -.4294(25.18) & -.3213(28.21) & -.2914(15.56) \\ \text { Separated/divorced } & .6994(46.68) & .3501(23.86) & .1820(18.23) & .1586(9.85) \\ \text { Widowed } & .9800(61.26) & .4647(29.63) & .1897(17.83) & .1519(8.82) \\ \text { Never married } & .3972(29.16) & .1694(12.69) & .0984(10.74) & .0343(2.34) \\ \text { Refusal } & .5558(6.79) & .2454(3.08) & .2466(5.53) & .1433(1.64) \\ \text { Unemployed }<12 m t h s & .2286(8.62) & .3260(12.53) & .3684(20.20) & .1315(4.61) \\ \text { Unemployed 12mths } & .2632(12.29) & .3904(18.61) & .5435(36.56) & .1831(7.95) \\ \text { Unable to work } & .6280(19.56) & .8923(28.40) & .6565(31.72) & .6143(17.80) \\ \text { Retired } & .1207(6.71) & .1252(7.10) & .1814(15.34) & -.0369(1.91) \\ \text { Homemaker } & .1675(9.01) & .1270(6.98) & .1481(12.29) & -.0186(0.93) \\ \text { Student } & -.0850(3.35) & -.0001(0.01) & -.0928(5.54) & .0103(0.38) \\ \text { Other } & .2618(4.67) & .2683(4.88) & .2118(6.24) & .3003(4.97) \\ 3^{\text {rd }} \text { sweep } & & & .0159(2.21) & \\ 4^{\text {th }} \text { sweep } & .0116(1.29) & .0225(2.54) & .0399(5.30) & -.0346(-3.56) \\ \text { cons } & 1.3906 & 1.6223 & 2.5646 & 2.5646 \\ \text { Adjusted R }{ }^{2} & .1466 & .1196 & .0997 & .0672 \\ \text { N } & 79,466 & 79,355 & 114,139 & 79,414\end{array}$

Equations include 37 country dummies Q17. Lonely. I have felt lonely - at no time=1; some of the time=2; less than half time=3; more than half the time=4; most of the time $=5$; all of the time $=6$ (waves $3 \& 4$ ).

Q18. Down. I have felt downhearted and depressed -at no time=1; some of the time=2; less than half time =3; more than half the time $=4$; most of the time $=5$; all of the time $=6$ (waves $3 \& 4$ ). Q19. Left out. I feel left out of society - never $=1$; less often/rarely=2; several times a year=3; several times a month=4; several times a week=5 (waves 2-4). Q20. Tense. I have felt particularly tense - at no time=1; some of the time=2; less than half time=3; more than half the time=4; most of the time $=5$; all of the time $=6$ ( waves $3 \& 4$ ). 
Appendix - Results without controls, ESS and EQLS

A) Table 5. ESS - includes country and wave dummies

$\begin{array}{llccc} & \text { Anxious } & \text { Feel a failure } & \text { Not hopeful } & \text { Life getting worse } \\ \text { Age 20-29 } & .0386(3.28) & -.0413(2.40) & -.0644(3.80) & .0646(4.09) \\ \text { Age 30-39 } & .0593(5.14) & .0071(0.42) & -.1126(6.75) & .1254(8.08) \\ \text { Age 40-49 } & .0852(7.46) & .0048(0.29) & -.1676(0.16) & .2015(13.13) \\ \text { Age 50-59 } & .1091(9.52) & .0092(0.55) & -.2674(6.15) & .2591(16.82) \\ \text { Age 60-69 } & .1059(9.10) & -.0724(4.26) & -.3446(0.49) & .2837(18.15) \\ \text { Age 70-79 } & .1630(13.25) & -.1077(5.99) & -.4314(4.24) & .2868(17.37) \\ \text { Age }>=80 & .1561(10.44) & -.1770(8.09) & -.4532(0.86) & .2716(13.51) \\ & & & & .2307 \\ \text { Adjusted R }{ }^{2} & .1314 & .1054 & .0870 & 92,382 \\ \mathrm{~N} & 93,221 & 93,181 & 92,189 & \end{array}$

B) Table 6. ESS - includes country and wave dummies

\begin{tabular}{lllll} 
& Lonely & \multicolumn{1}{c}{ Sad } & Depressed & Restless sleep \\
Age 20-29 & $.0291(2.90)$ & $.0006(0.06)$ & $.0228(2.40)$ & $.0861(7.29)$ \\
Age 30-39 & $-.0028(0.29)$ & $.0034(0.37)$ & $.0350(3.75)$ & $.1202(10.38)$ \\
Age 40-49 & $.0161(1.66)$ & $.0455(4.92)$ & $.0735(7.95)$ & $.1553(13.54)$ \\
Age 50-59 & $.0554(5.70)$ & $.0832(8.98)$ & $.1142(12.34)$ & $.2456(21.39)$ \\
Age 60-69 & $.0853(8.67)$ & $.0933(9.96)$ & $.1098(11.73)$ & $.2671(23.00)$ \\
Age 70-79 & $.2103(20.20)$ & $.1717(17.33)$ & $.1874(18.91)$ & $.3494(28.47)$ \\
Age $>=80$ & $.4035(32.37)$ & $.2566(21.61)$ & $.2657(22.36)$ & $.3713(25.26)$ \\
& & & & \\
Adjusted $\mathrm{R}^{2}$ & .0668 & .0808 & .0713 & .0350 \\
$\mathrm{~N}$ & 133,007 & 132,993 & 132,968 & 133,303
\end{tabular}

C) Table 7. EQLS - includes country and wave dummies

$\begin{array}{lllll} & \text { Lonely } & \text { Down \& depressed } & \text { Left out } & \text { Tense } \\ \text { Age 20-29 } & .0907(2.78) & .1443(4.61) & .0463(2.28) & .0924(2.28) \\ \text { Age 30-39 } & .1223(3.79) & .2250(7.27) & .1022(5.11) & .2039(5.11) \\ \text { Age 40-49 } & .1789(5.57) & .2946(9.55) & .1278(6.40) & .2473(6.40) \\ \text { Age 50-59 } & .2435(7.58) & .3586(1.63) & .1526(7.63) & .2269(7.63) \\ \text { Age 60-69 } & .2239(6.95) & .2909(9.40) & .1210(6.03) & -.0073(6.03) \\ \text { Age 70-79 } & .4766(14.39) & .4597(4.46) & .1917(9.27) & .0020(9.27) \\ & & & & \\ \text { Adjusted R } & .0641 & .0727 & .0597 & .0534 \\ \text { N } & 80,026 & 79,916 & 115,305 & 79,976\end{array}$




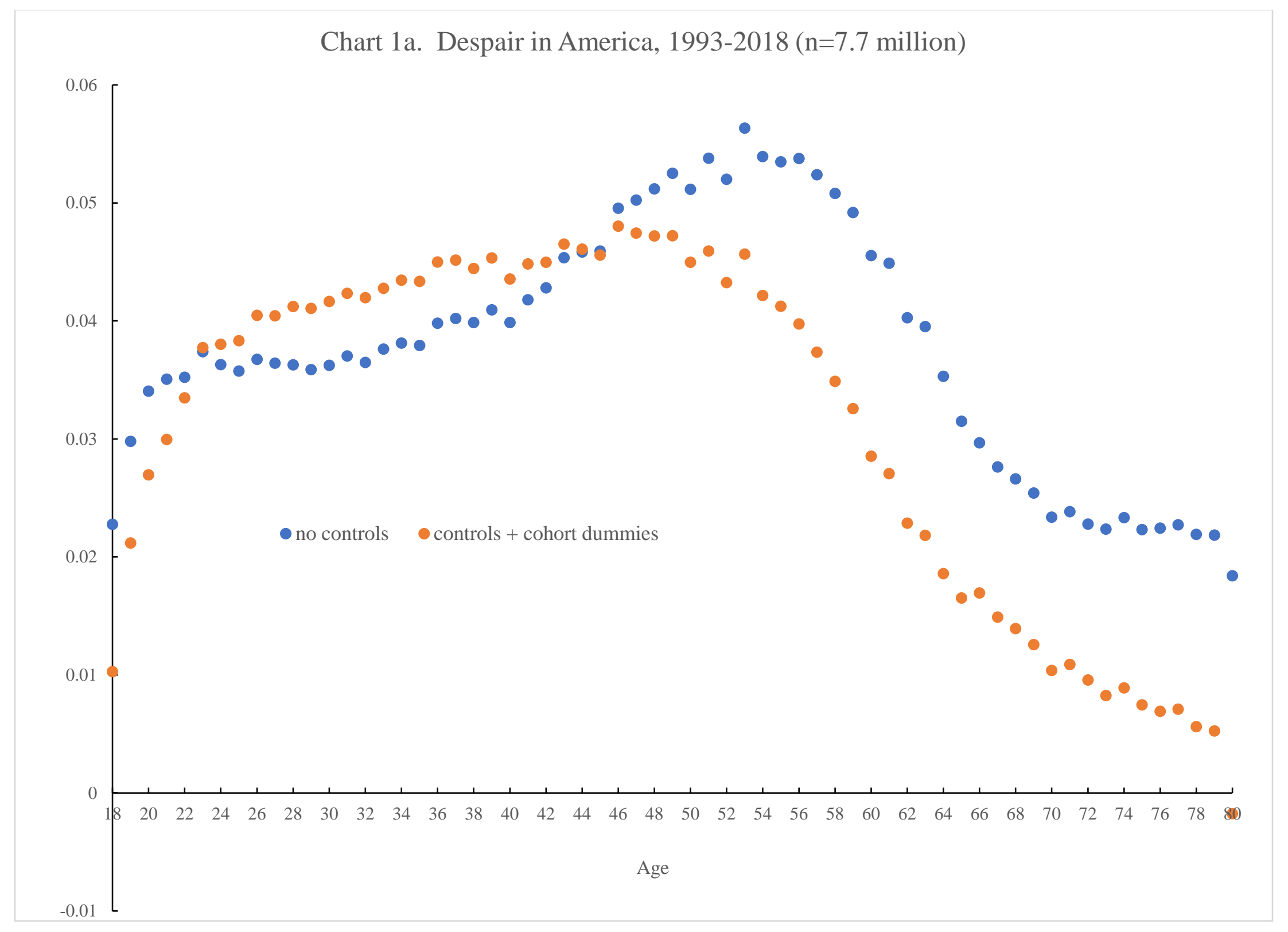



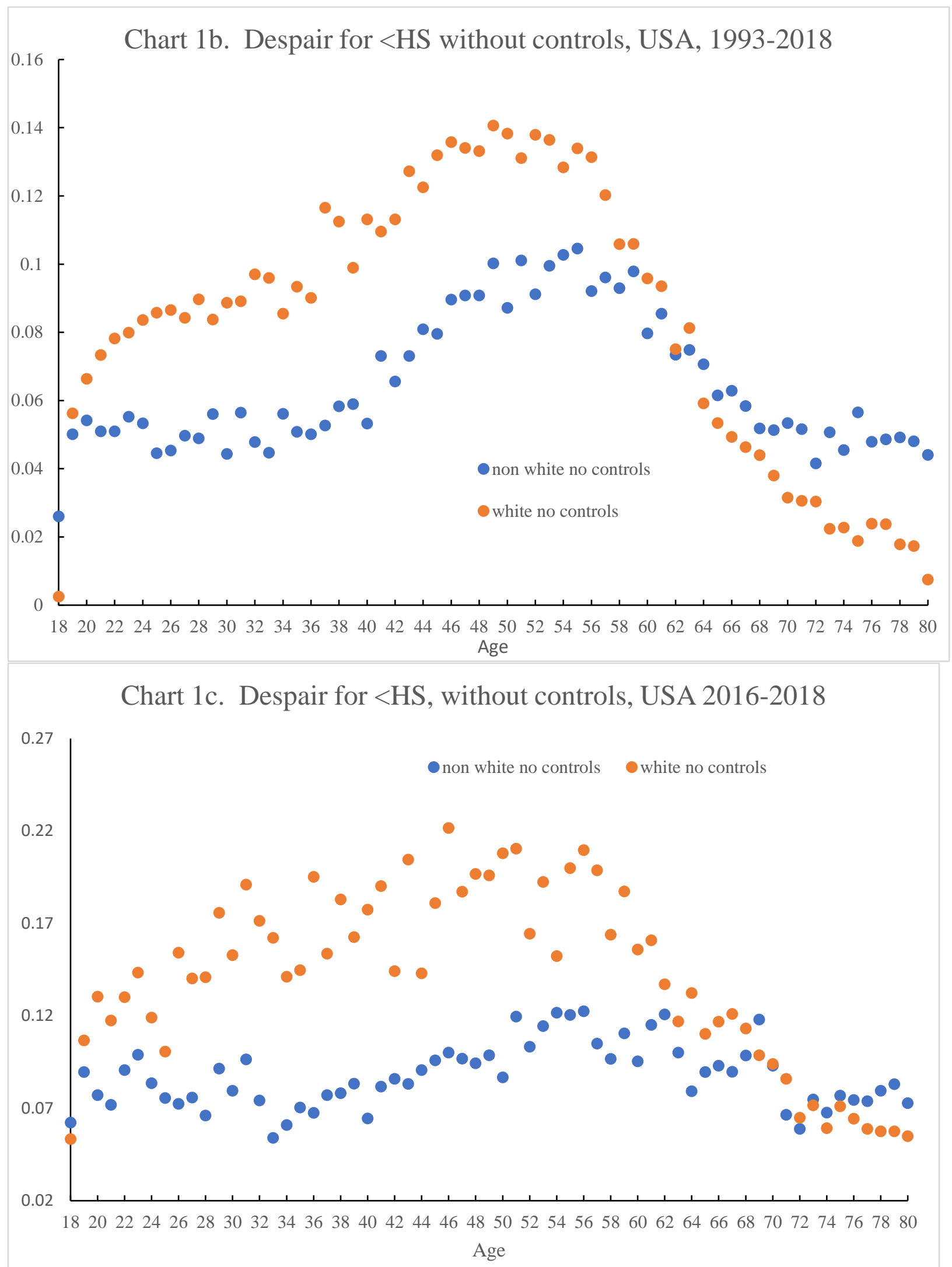


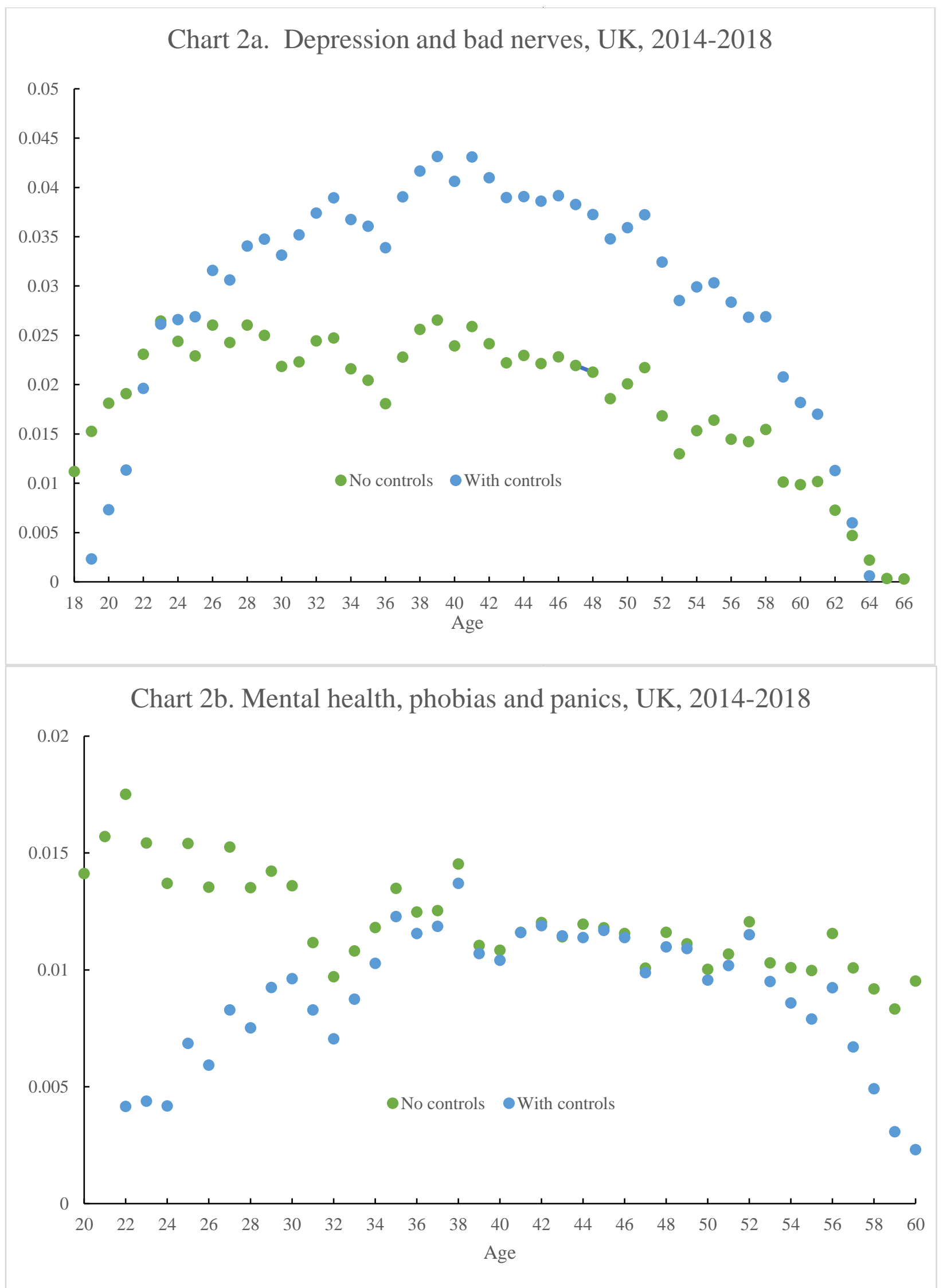




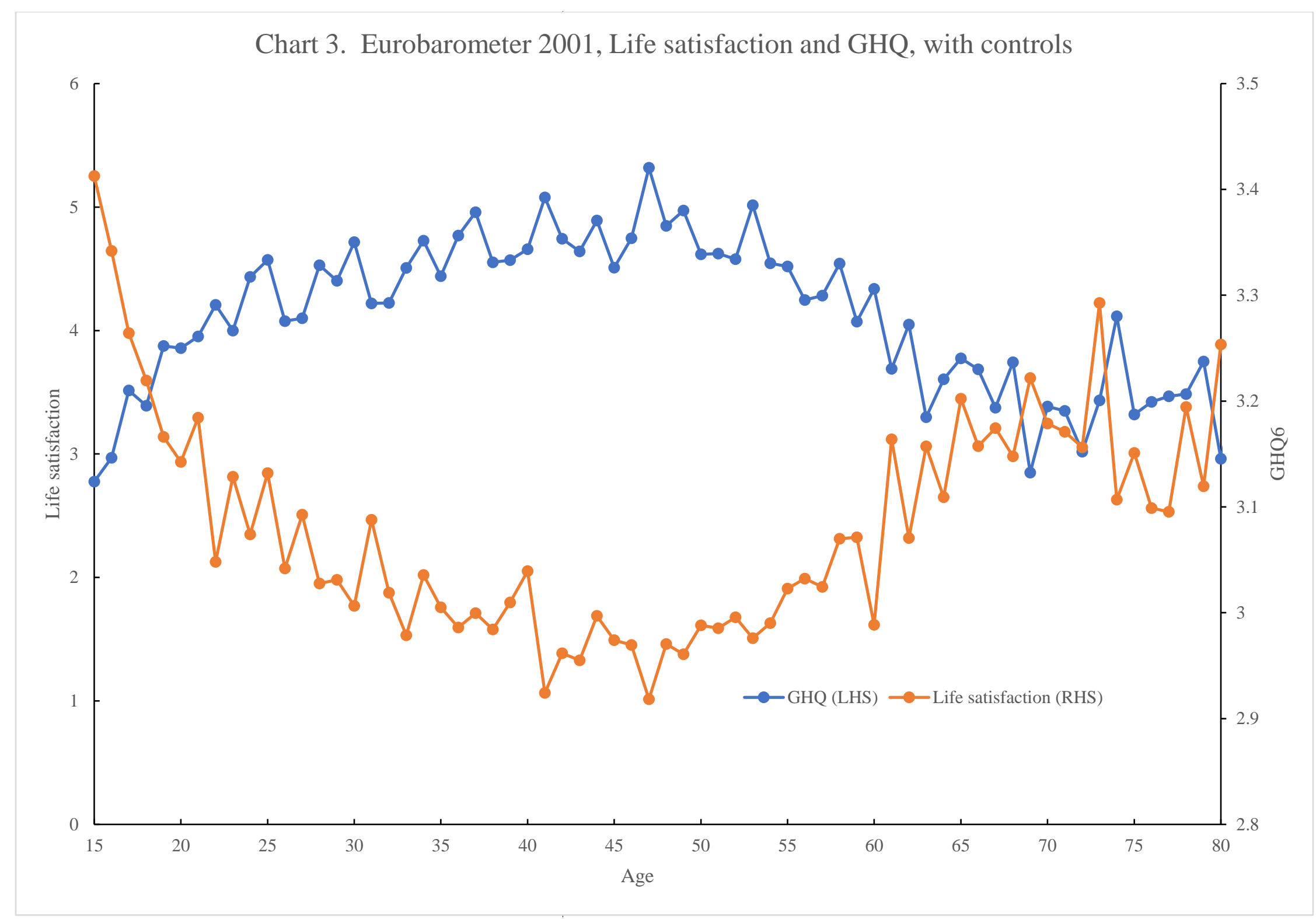




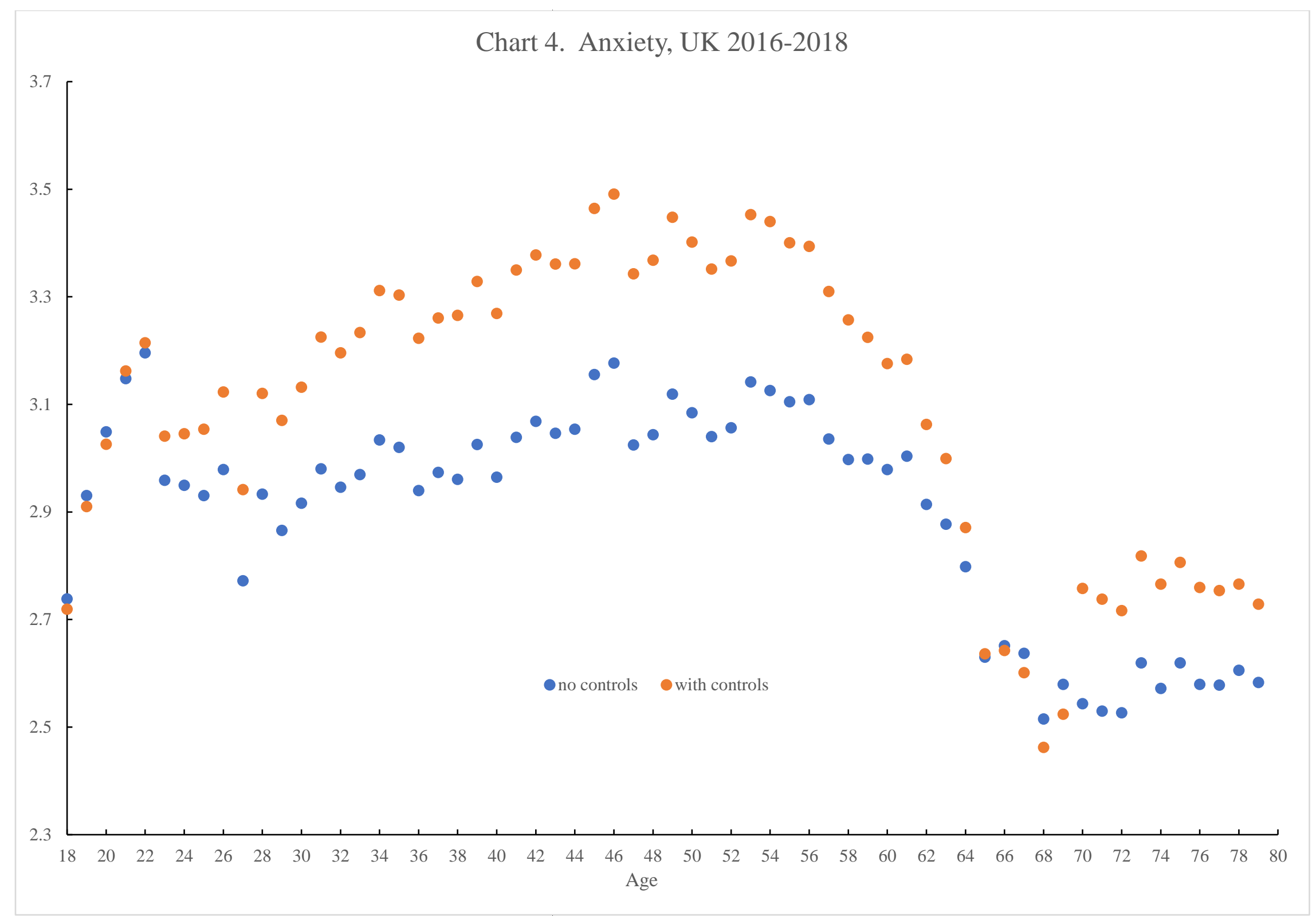

